\title{
Beyond Insolvency
}

\author{
Vincent S. J. Buccola*
}

\section{INTRODUCTION}

A common dynamic in contested Chapter 11 proceedings pits a firm's shareholders against its creditors. Unable to pay debts as they come due, the firm has petitioned for relief from creditors' immediate attempts to levy on firm assets. The bankruptcy judge will decide how best to reorganize the debtor firm. Shareholders argue that the firm should continue operations and that it needs bankruptcy relief primarily to restructure current debt burden. The firm will be profitable, shareholders argue, and consequently they deserve to participate to some extent in the restructured enterprise. The creditors see things differently. The creditors argue that the firm's operations are inefficient, that the best thing to do is liquidate assets, with proceeds going to satisfy debts before shareholders take a dime. Shareholders and creditors have roughly equal information about the firm's operations and prospects, yet they systematically disagree about the prudent course of action. Shareholders want to continue operations; creditors want to liquidate.

This dynamic is an example of a more general, persistent tension between investors with hierarchically differentiated claims on a firm's assets-what this Article calls "vertical investor conflict." In a firm with a single class of investor (say, shareholders), the investors maximize the value of their investment by maximizing the firm's expected profitability. In choosing between two ventures, one risky and one safe, the investors ask themselves only whether the risk associated with the first project is offset by the returns it promises to generate if successful. If the project is risk-justified, the investors want to pursue it; if not, they want the firm to steer clear of the risk. In this way such a firm directs its assets to the projects society values most highly-in expectation,

\footnotetext{
* Bigelow Teaching Fellow and Lecturer in Law, the University of Chicago Law School. I thank Daniel Abebe, Douglas Baird, Anya Bernstein, Alex Boni-Saenz, Steve Buccola, Tony Casey, JB Heaton, Todd Henderson, Ashley Keller, Saul Levmore, Jennifer Nou, Greg Reilly, Victoria Schwartz, and David Skeel for their thoughtful conversation and assiduous criticism of earlier drafts.
} 
anyway. Things become more complicated when a class of creditors is introduced. The creditors, who have the right to be paid their debt but no more, favor the steady course even if the risky one could pay off big. Meanwhile the shareholders, who because of limited liability owe creditors no personal obligation if the firm fails, favor the risky venture. If the gamble pays off, the shareholders enjoy a sizeable return. If not, they offload at least part of their losses on the creditors. Neither shareholder nor creditor thinks the way a sole owner thinks.

Vertical investor conflict is a chronic problem in modern business organizations. Because the preferences of investors in a hierarchically differentiated firm differ from those in an equity-only firm, the conflict threatens to divert resources from their socially optimal use. What is less clear is what, if anything, the law has to say about resolving these conflicts. In general, a firm's managers are entrusted to decide how to use its assets. The question this Article takes up is how, if at all, the law should intervene when management's view of the best course appears to be colored by investors' divergent preferences.

Courts that have addressed vertical investor conflict explicitly have framed the problem as one of fiduciary obligation. Managers decide in the first instance what to do, but they are obliged to decide in accordance with their duty of loyalty. But loyalty to whom? Beginning with the seminal case of Credit Lyonnais v. Pathe Communications, ${ }^{1}$ Delaware's chancery and supreme courts have articulated a rule of corporate law under which the direction of management's fiduciary duty of loyalty depends on the firm's solvency. Managers of a solvent firm owe obligations to shareholders only, not to creditors, ${ }^{2}$ but managers of an insolvent firm or a firm "in the vicinity of insolvency" may be required to take creditor as well as shareholder interests into account; they must consider what is best for a "community of interests." 3 As a matter of fiduciary principles, in other words, managers of a solvent firm may-

1. Credit Lyonnais Bank Nederland, N.V. v. Pathe Commc'ns Corp., No. Civ.A.12150, 1991 WL 277613 (Del. Ch. Dec. 30, 1991).

2. See Katz v. Oak Indus. Inc., 508 A.2d 873, 879 (Del. Ch. 1986) (stating that no fiduciary duty is owed to creditors absent legislative action or expressly contracted indenture provisions).

3. Credit Lyonnais, 1991 WL 277613, at*1155 n.55; see also Prod. Res. Grp., v. NCT Grp., 863 A.2d 772, $790 \mathrm{n} .57$ (Del. Ch. 2004) (finding that managers of a firm that is near insolvency may be required to pursue a strategy that gives preference to neither stockholders nor creditors). But see N. Am. Catholic Educ. Programming Found., Inc. v. Gheewalla, 930 A.2d 92, 101 (Del. 2007) (holding that "no direct claim for breach of fiduciary duties may be asserted by the creditors of a solvent corporation that is operating in the zone of insolvency"). 
indeed, must-prefer shareholders over creditors. ${ }^{4}$ Managers of an insolvent or nearly insolvent firm face a more diffuse and hence less restrictive set of loyalties. ${ }^{5}$

In the two decades since Credit Lyonnais, legal scholars have devoted numerous papers to critiquing this duty-shifting regime. Commentators have variously argued that managerial loyalty should run exclusively in favor of shareholders; ${ }^{6}$ that it should run in favor of creditors, ${ }^{7}$ that loyalty requires managers to act for a hypothetical, sole investor; ${ }^{8}$ and that judicially enforceable fiduciary obligations should be abolished altogether. ${ }^{9}$ Scholarly opinions vary, but they share the common assumption that, as a doctrinal matter, the duty of loyalty embodies the norms by which business managers are expected to resolve vertical investor conflict. Scholarly debate has in other words turned on the way courts articulate, or should articulate, fiduciary standards.

Another common thread runs through the existing literature. In general, scholars have devoted little attention to how the fiduciary ideals they promote can be enforced in a world where the business judgment rule looms large. ${ }^{10}$ Ideals are well and good for managers who seek to

4. The focus here is Delaware corporate law because of its pervasive influence on questions of corporate governance. Some states have declared by statute that managers may take the interests of non-shareholder constituencies into account. In Oregon, for example, directors evaluating a tender offer may "give due consideration to the social, legal and economic effects on employees, customers and suppliers of the corporation and on the communities and geographical locations in which the corporation and its subsidiaries operate ...." OR. REV. STAT. § 60.357(5) (2003).

5. In Gheewalla, the Delaware Supreme Court held that the obligation to creditors identified in Credit Lyonnais does not imply a cause of action for breach of the duty of loyalty. 930 A.2d at 99-101. The duty to creditors serves, in other words, as a shield to protect managers from liability to shareholders but not as a sword for creditors to assert wrongdoing.

6. See, e.g., Stephen M. Bainbridge, In Defense of the Shareholder Wealth Maximization Norm: A Reply to Professor Green, 50 WASH. \& LEE L. REV. 1423, 1446-47 (1993) [hereinafter Bainbridge, Defense]; Henry T. C. Hu \& Jay Lawrence Westbrook, Abolition of the Corporate Duty to Creditors, 107 Colum. L. REV. 1321, 1402-03 (2007)

7. Morey W. McDaniel, Bondholders and Corporate Governance, 41 BuS. LAW. 413, 456 (1986) [hereinafter McDaniel, Corporate Governance]; Morey W. McDaniel, Bondholders and Stockholders, 13 J. CORP. L. 205, 313-15 (1988) [hereinafter McDaniel, Stockholders].

8. Thomas A. Smith, The Efficient Norm for Corporate Law: A Neotraditional Interpretation of Fiduciary Duty, 98 Mich. L. REV. 214, 268 (1999); see also Laura Lin, Shift of Fiduciary Duty upon Corporate Insolvency: Proper Scope of Directors' Duty to Creditors, 46 VAND. L. REv. 1485, 1524 (1993) (arguing that an asset-value-maximization norm is efficient but that creditors should be required to bargain for explicit contractual rights rather than benefit from a freestanding fiduciary obligation).

9. Douglas G. Baird \& M. Todd Henderson, Other People's Money, 60 STAN. L. Rev. 1309, 1315 (2008).

10. Lin, supra note 8 , at $1506-07$, is a notable exception. Lin posits that "[e]xtending the business judgment rule to shield the directors' business decisions when they are challenged by 
fulfill their legal obligations whatever the practical consequences. They may even exert important expressive power. ${ }^{11}$ To the self-interested manager, however, they have little to say. To the self-interested manager, a robust business judgment rule looks scarcely different from a world in which fiduciary obligations are formally defunct. The question of deference must be central to any practical criticism of existing doctrine, and in this sense the literature has failed to engage with perhaps the most important consequence of Credit Lyonnais and its ilk. On its face, Credit Lyonnais appeared to reduce managerial discretion by creating a previously unknown duty of loyalty to creditors. But it did so by adding a new class of beneficiaries - namely creditors - to the fiduciary fold. The decision thus charged managers with caring for a diffuse "community of interests" comprising shareholders as well as creditors, no one member of which has any particular claim of right. ${ }^{12}$ With no metric by which to judge a manager's success or failure, the effect of Delaware's jurisprudence since Credit Lyonnais therefore may have been to insulate management decision-making through an expansion of the business judgment rule's domain.

This Article argues that scholarly debate over vertical investor conflict (and Delaware case law in particular) has missed the mark. First, on the question of ideals, this Article challenges the unanimous assumption that fiduciary duty holds the doctrinal key to vertical investor conflict. Preoccupation with the role of fiduciary duty might be attributable to myopia inherent in the discrete jurisdictions of the courts and, to a lesser degree, of the academy. Courts accustomed to hearing equitable claims may find it natural to frame problems in terms of

creditors can alleviate th[e] concern for potential abuse." Id. The business judgment rule says that courts will not second-guess a disinterested manager's good-faith decisions made with due care. E.g., In re Citigroup S'holder Deriv. Litig., 964 A.2d 106, 122 (Del. Ch. 2009) (stating that the business judgment rule "prevents judicial second guessing of the decision if the directors employed a rational process and considered all material information reasonably available"). It is a rule of deference, albeit one with play in the joints. For example, the concept of due care has proved elastic in the hands of a suspicious court. See, e.g., Smith v. Van Gorkom, 488 A.2d 858, 871 (Del. 1985) (reversing the chancery court's application of the business judgment rule even though the directors claimed to be "well-informed").

11. See generally Jonathan C. Lipson, The Expressive Function of Directors' Duties to Creditors, 12 Stan. J. L. BUS. \& Fin. 224, 228 (2007) (exploring the "expressive holdings" of judges who suggest that corporate directors owe creditors fiduciary duties during periods of financial distress, yet who refuse to formally hold so).

12. Credit Lyonnais Bank Nederland, N.V. v. Pathe Commc'ns Corp., No. Civ.A.12150, 1991 WL 277613, 1156 (Del. Ch. Dec. 30, 1991). 
fiduciary obligation - an example of Kaplan's law of the instrument. ${ }^{13}$ Whatever the reason, courts and commentators have paid insufficient attention to the ways in which general debtor-creditor law aims to influence corporate management in the ordinary course. This Article argues as a descriptive matter that longstanding fraudulent transfer principles point toward an existing norm of asset-value maximization. For five hundred years, fraudulent transfer law has prohibited debtors from intentionally "delaying, hindering, or defrauding" creditors. ${ }^{14}$ This Article offers a theory of fraudulent transfer which, in combination with a traditional, shareholder-focused conception of fiduciary duty, describes a norm under which a manager should seek to maximize the expected value of her firm's assets. On this theory, in other words, a manager can simultaneously satisfy her duty of loyalty to shareholders and the firm's obligations to creditors only by seeking to maximize the firm's expected value to investors as a whole. ${ }^{15}$

Proponents of a value-maximization norm are on sure footing as a descriptive matter. The critical question becomes one of institutional competence. As a realistic matter, that is, one has to ask to what extent asset-value maximization is an enforceable norm and not just a piece of wishful thinking. In doctrinal terms the question is how robustly courts ought to interpret rules of deference to management. ${ }^{16}$ Decisions such as Credit Lyonnais and Gheewalla suggest that, from Delaware's perspective, at least, judicial second-guessing is a nonstarter. ${ }^{17}$ This

13. Abraham Kaplan describes the "law of the instrument" as: "Give a small boy a hammer, and he will find that everything he encounters needs pounding." ABRAHAM KAPLAN, THE CONDUCT OF INQUiRY: METHOdOLOGY FOR BEHAVIORAL SCIENCE 28 (Transaction Publishers, 4th prtg., 2004) (1964).

14. The formulation dates to Queen Elizabeth's reign. 1570, 13 Eliz., c. 5 (Eng.).

15. Others have argued that a rule of asset-value maximization is economically rational. See, e.g., Smith, supra note 8, at 214-18; Lin, supra note 8, at 1497; see also Baird \& Henderson, supra note 9, at 1313 (describing this view as dominant among economists and legal scholars influenced by economic theory). Some courts have found a corresponding norm in the federal law applicable to debtors in bankruptcy. See, e.g., In re Cent. Ice Cream Co., 841 F.2d 732, 734-75 (7th Cir. 1987).

16. When shareholders allege breach of fiduciary duty, the rule of deference is the business judgment rule. In re Citigroup S'holder Deriv. Litig., 964 A.2d 106, 122 (Del. Ch. 2009). When creditors allege fraudulent transfer, there is a corresponding principle of deference-namely, the requirement that the creditor prove bad intent. See, e.g., DEL. Code ANn. tit. 6, § 1304 (2012) (prohibiting transfers made by a debtor " $[\mathrm{w}]$ ith actual intent to hinder, delay or defraud any creditor of the debtor").

17. See Credit Lyonnais, 1991 WL 277613, at *1143 (Del. Ch. 1991) ("I do not conclude lightly or easily that the covenant of good faith and fair dealing was violated here. The entire course of conduct of defendant ... does, however, force me to that conclusion."); N. Am. Catholic Educ. Programming Found., Inc. v. Gheewalla, 930 A.2d 92, 99 (Del. 2007) ("Delaware courts have traditionally been reluctant to expand existing fiduciary duties."). 
Article argues that the degree to which courts defer to managerial decisions should depend on the quality of market signals available. For firms with widely traded securities, the Article shows how capital markets can give teeth to an asset-value-maximization norm within the framework of existing causes of action for breach of fiduciary duty and fraudulent transfer. By observing changes in the market prices of a firm's securities after management has announced a strategic plan, courts can learn valuable information, at low cost, about whether a manager has (or has not) deviated from the law's ideal. The threat of accurate and inexpensive litigation can be expected in turn to improve managerial discipline. Litigation holds less promise of identifying wrongdoing in the case of closely held firms, and consequently judicial deference should be at its maximum when investors in close firms challenge managerial decisions. And yet, this Article argues, the close firm is not a hopeless case. It is in precisely the close context where, because of low transaction costs, managers are most likely to maximize asset value without legal intervention.

But this anticipates too much. Before we can hope to judge the utility of particular rules we must understand more fully the dynamic that generates vertical investor conflict and the ways in which managers can be expected to resolve it absent legal intervention. Although the basic phenomenon of conflict is widely observed and well documented, the legal literature lacks a comprehensive account of its dimensions. Part II of this Article seeks to provide such an account. To that end it develops a unique model of a two-investor-class firm operating in a two-period world. Consistent with experience, the model predicts that conflict will increase with a firm's financial distress. It is under conditions of distress that shareholders and creditors alike will most aggressively agitate for the firm to use assets in a socially suboptimal manner. Yet the model also shows that there is nothing magical about insolvency-the point at which debts exceed asset value. Vertical investor conflict builds continuously, before and after a firm becomes insolvent, and in this sense the model suggests that a duty-shifting regime is hard to justify. Part II then seeks to understand how managers unconstrained by law will resolve investor conflict. To the extent managers have incentives to maximize asset value without the threat of judicial intervention, the error and administrative costs associated with intervention will appear wasteful. Although under certain conditions managers can be expected to resolve conflict through a value-maximizing use of assets, Part II shows that these conditions are difficult to observe. It is not possible to predict as a general matter whether a manager faced with conflict will 
favor shareholders, favor creditors, or act to maximize the firm's expected value.

Part III turns to the ideals embodied in our law. In light of the ambiguous way in which managers can be expected to react to vertical investor conflict, this Part asks how law would have them behave. It begins with a survey of existing judicial and scholarly commentary on the subject, highlighting the doctrinal focus on competing rules of fiduciary duty. It then develops a theory of fraudulent transfer which, read in combination with a traditional vision of fiduciary duty, points to an ideal of asset-value maximization.

Part IV takes up the problem of realizing this ideal through concrete legal intervention. In particular, it evaluates the means by which law can encourage self-interested managers to abide to the asset-valuemaximization norm where questions of institutional competence and collateral costs loom large. This Part argues that legal intervention holds most promise where markets efficiently price a firm's securities and, therefore, that judicial deference to management should be at its lowest in these circumstances. In the case of closely held firms, by contrast, this Part argues that legal intervention can do little to discipline managers effectively.

\section{CAUSES AND CONSEQUENCES OF VeRTiCAL INVESTOR CONFLICT}

It is no secret that shareholders and creditors of a business firm often disagree about how the firm should use its assets. They may, for example, disagree about the expected profitability - the relative risks and rewards - of projects available to the firm. If a widget manufacturing firm is deciding whether to build a new factory, shareholders and creditors might differ in their views on the market for widgets. A shareholder could believe that demand for widgets is very likely to grow in the next ten years. With additional capacity, she might think, the firm will be able to take advantage of consumer demand. A creditor could take the opposite view, that widgets are a fad and that the firm consequently will not be able to recoup its investment in the new facility. This is a conflict over predictions about facts and the expected effect of a firm's activities on its balance sheet, and corporate law furnishes a straightforward resolution. It assigns the decision to the firm's management. ${ }^{18}$ Shareholders can remove directors by vote, but in

18. A small number of extraordinary corporate actions require stockholder consent. In 
general an investor who is unhappy with management's resolution of this kind of dispute must find what solace she can in the marketplace, by selling her interest in the firm.

A balance-sheet dispute can arise between any two investors. There is nothing special about one's identity as a shareholder or creditor. Balance-sheet disputes thus are an example of what one can call horizontal investor conflict: conflict in which the investors' relative priority in a hierarchical capital structure plays no role. This Article is concerned with vertical conflict. Vertical investor conflict arises even where all agree about the expected risks and rewards of a firm's activities (and potential activities) to its balance sheet. Prediction about the future, interpretation of facts relevant to the firm's business, is not decisive. In this sense vertical investor conflict poses questions of corporate lawwho decides how the conflict should be resolved, and according to what standard? - that may have answers different from horizontal investor conflict. The key to vertical investor conflict is not "outside" the firm, in its relations with other persons. It is rather built into the very nature of hierarchically organized capital structures. Before turning to ways in which the law responds (or could respond) to vertical investor conflict, we must first learn to diagnose it and to assess how managers are likely to respond to it.

\section{A. Diagnosing Vertical Investor Conflict}

To begin, imagine a firm, Acme, with a single class of equity. At time 0, Acme borrows from its lone creditor and issues a $\$ 100$ note payable at time 1 . At time 0 , Acme's manager is confronted with three mutually exclusive projects the firm could pursue. One is risky, one safe, and one entails intermediate risk. Imagine further that everyone agrees on Acme's payoff possibilities at time 1. Relative to time 0, Project $A$ has a $50 \%$ chance of earning $\$ 40$, and a $50 \%$ chance of losing $\$ 80$, for an expected value of $\$-20$. Project $B$ has a $100 \%$ chance of losing $\$ 5$. This might be a divestment of a division. Project $C$ has a $50 \%$

Delaware, for example, stockholders must approve a decision to merge or dissolve the firm. DEL. CODE ANN. tit. $8 \S \S 251$ (c) (merger), 275 (dissolution) (2012). In general, though, the firm's officers, acting under the supervision of the board of directors, are competent to decide most questions on which a predictive dispute could arise. DEL. CODE ANN. tit. 8 § 142(a) (2012). Some questions are reserved to the board itself. For my purposes in this Article, the assignment of a question to the board or to officers acting under the board's supervision is irrelevant. Consequently this Article ignores the identity of the representative and refers generally to the firm's "management" or, at the risk of too much simplification, its "manager." 
chance of earning $\$ 20$ and a $50 \%$ chance of losing $\$ 10$, for an expected value of $\$ 5$.

Summary of expected effects on Acme's balance sheet

\begin{tabular}{|l|c|c|c|}
\hline & Project $A$ & Project $B$ & Project $C$ \\
\hline Expected Balance Sheet & -20 & -5 & 5 \\
\hline
\end{tabular}

Which of the projects will the shareholders and the creditor prefer? If a single investor owned the entire firm (the equity and the debt), it is easy to see what she would want. She would unambiguously prefer Project $C .{ }^{19}$ The answer is more complicated, though, when the equity and debt are held by different persons.

A financially healthy firm approximates the single-owner result. Suppose that at time 0 Acme holds assets with a liquidation value of $\$ 2,000$. By hypothesis the creditor's principal is assured under any scenario. At worst, Acme will lose $\$ 80$ over the period from time 0 to time 1. The remaining assets, worth $\$ 1,920$, are more than enough to satisfy the creditor's claim (i.e., $\$ 100$ ). Thus, the creditor is indifferent between the projects. Shareholders, meanwhile, will unambiguously prefer Project $C$. In this healthy state, the shareholders internalize all expected losses (because the creditor is fully secured), as well as all expected gains (because the creditor's principal and interest rate are set). The shareholders prefer the project with an expected $\$ 5$ gain.

But now suppose another firm, Acme', identical to Acme in every way except that it is financially distressed. Acme' owns assets worth $\$ 105$. Setting aside option value, the equity is worth $\$ 5$. Which project do the investors in Acme' want the firm to pursue? Plainly, the investors' preferences have diverged. Shareholders will agitate for the firm to pursue Project $A$. Project $A$ entails a 50\% chance that their $\$ 5$ of equity will be wiped out and a $50 \%$ chance they will earn $\$ 40$. Shareholder's expected return from Project $A$ is $\$ 17.50$. Projects $B$ and

19. This Article assumes throughout that all investors are privately risk-neutral - that is, that investors' utility of a dollar received from the firm describes a linear function. This is a common assumption, because although the risk tolerances of real individuals are heterogeneous, investors may hedge risk they want to avoid (and may take on additional risks they want to incur) through investments outside the firm. See, e.g., FRANK H. EASTERBROOK \& DANIEL R. FisCHEL, THE ECONOMIC STRUCTURE OF CORPORATE LAW 29-30 (1991). Even if investors cannot perfectly hedge risk through diversification, this Article's claims hold as long as the aggregate risk tolerances are symmetric across the capital structure. If there is no reason to think that bondholders, say, are systematically more or less risk-tolerant than shareholders, then one could easily correct this Article's results from dollars into utils. 
$C$ hold far worse prospects. Project $B$ is certain to wipe out shareholder equity. If Acme' undertakes Project $C$, the shareholders face a $50 \%$ chance that their equity will be wiped out and a $50 \%$ chance that they will earn $\$ 20$. Their expected return, $\$ 7.50$, is smaller than the $\$ 17.50$ they expect from Project $A$.

Arithmetic shows that the creditor's ranked preferences are opposite to those of the shareholders. If Acme' undertakes Project $A$, there is a $50 \%$ chance that the creditor will recover his entire principal and a 50\% chance that he will lose $\$ 75$ (expected loss of $\$ 37.50$ ). Project $B$ is sure to leave the creditor unimpaired. And Project $C$ promises a 50\% chance of full recovery and a $50 \%$ chance of a $\$ 5$ loss (expected loss of \$2.50).

Summary of Expected Payouts (Acme')

\begin{tabular}{|c|c|c|c|}
\hline & Project $A$ & Project $B$ & Project $C$ \\
\hline Shareholders & $\mathbf{1 7 . 5 0}$ & -5 & 7.50 \\
\hline Creditor & -37.50 & $\mathbf{0}$ & -2.50 \\
\hline Sole Owner & -20 & -5 & $\mathbf{5}$ \\
\hline
\end{tabular}

This simple example illustrates an important dynamic that holds true in more complicated models. Divergence of interest between shareholders and creditors - in fact, between any two classes of investor with hierarchical rights to a firm's cash flows - depends on the firm's financial health rather than anything peculiar to the investors themselves. As a firm approaches insolvency, its shareholders stand to gain from earnings, but because of their limited liability, suffer only a portion of losses. Limited liability allows them to externalize risk. Conversely, losses impair the creditor's interest in a manner that corresponding gains will not offset (because, at the beginning of any period, the creditor's maximum return is fixed). The creditor will urge the firm to forego even expectation-justified risky projects.

Investors and financial economists have long grasped the fundamental problem of vertical investor conflict and the correlative question of risk alteration. ${ }^{20}$ But although the literature on corporate governance recognizes the issue, scholars in the field have until now been content to point to it only in a general way. ${ }^{21}$ My aim in this Article

20. See, e.g., Hideki Kanda \& Saul Levmore, Explaining Creditor Priorities, 80 VA. L. Rev. 2103, 2105-06 (1994); Michael C. Jensen \& William H. Meckling, Theory of the Firm: Managerial Behavior, Agency Costs and Ownership Structure, 3 J. Fin. ECON. 305, 309-10 (1976); EugENE F. FAMA \& MERTON H. MiLleR, THE THEORY OF FinANCE 120 (1972).

21. See supra note 20. 
is to evaluate the law's response to vertical investor conflict. To do so, we must develop the problem more systematically than legal scholars have done - to understand where vertical investor conflict is likely to emerge, and to what degree.

We can continue with the straightforward assumption that both shareholders and creditors attempt to maximize the expected value of their respective interests. By comparing the investors' profit identities, we can learn under what conditions and to what extent the interests will conflict. Assume a two-period world. At time 0, the firm has assets worth $A_{0}$ and an outstanding debt of $P_{0}$, due at time 1 . Putting aside option value for the moment, the value of equity at time 0 is $E_{0}=A_{0}-$ $P_{0}{ }^{22}$ At time 0 the firm will undertake a portfolio of projects the returns on which (at time 1) are normally distributed with an identifiable mean $(\mu)$ and variance $(\sigma)$. In other words, the investors and manager agree on the expected value and risk of the firm's projects. Thus, $A_{1}$ is a random variable and expected $A_{1}=A_{0}+\mu$.

Start with the shareholder's profit identity. The crucial fact here is the doctrine of limited liability, under which a creditor may not hold shareholders to the fire for defaults on principal due. ${ }^{23}$ The future value of asset $\mathrm{A}$ is random, because the future is uncertain, but it can be defined as follows:

(1) $E_{1}=\left[\begin{array}{cc}A_{1}-P_{0} & \text { if } A_{1}>P_{0} \\ 0 & \text { if } A_{1} \leq P_{0}\end{array}\right]$.

Equity at time 1 is the difference between time 1 asset value and debt if that difference is positive, and zero otherwise. Equity $E_{1}$ is, like $A_{1}$, a random variable, but with a discontinuous distribution. Its expected value is

(2) $\overline{E_{1}}=\left\{\left[\overline{A_{1}}+\left(\frac{\varphi\left(\frac{P_{0}-\overline{A_{1}}}{\sigma}\right)}{1-\Phi\left(\frac{P_{0}-\overline{A_{1}}}{\sigma}\right)}\right) \sigma\right]-P_{0}\right\}\left[\operatorname{prob}\left(A_{1}>P_{0}\right)\right]$,

namely the expected difference between asset value and debt if that difference is positive, times the probability that the difference will be

\footnotetext{
22. One can think of $E_{0}$ as the value shareholders would recover if the firm were liquidated at time 0 .

23. See generally Jensen \& Meckling, supra note 20, at 331.
} 
positive. If, as we will assume here along with much of the literature, asset value $A_{1}$ is normally distributed, $\overline{E_{1}}$ is the expected value of the truncated portion of the normal distribution above debt $P_{0}$, assuming $P_{0}$ has been netted out of every asset realization before it is awarded to the shareholder.

Equation (2) then just says that shareholders' expected equity value is the product of that truncated mean and the probability that $A_{1}>P_{0}$.

Employing the formula for the mean of the relevant truncated portion of the normal density function, namely where shareholder return goes to zero when asset value equals or falls short of debt $P_{0}$, gives

$$
\begin{gathered}
\overline{E_{1}}=\left\{\left[\overline{A_{1}}+\left(\frac{\varphi\left(\frac{P_{0}-\overline{A_{1}}}{\sigma}\right)}{1-\Phi\left(\frac{P_{0}-\overline{A_{1}}}{\sigma}\right)}\right) \sigma\right]-P_{0}\right\}\left[1-\Phi\left(\frac{P_{0}-\overline{A_{1}}}{\sigma}\right)\right] \\
=1-\Phi\left(\frac{P_{0}-\overline{A_{1}}}{\sigma}\right)\left(\overline{A_{1}}-P_{0}\right)+\varphi\left(\frac{P_{0}-\overline{A_{1}}}{\sigma}\right) \sigma
\end{gathered}
$$

where $\left(P_{0}-\overline{\mathrm{A}}\right) / \sigma=z$ is the standard-normal variate. Multiplying through gives

(4) $\overline{E_{1}}=\left[1-\Phi\left(\frac{P_{0}-\overline{A_{1}}}{\sigma}\right)\right] \overline{A_{1}}+\varphi\left(\frac{P_{0}-\overline{A_{1}}}{\sigma}\right) \sigma-\left[1-\Phi\left(\frac{P_{0}-\overline{A_{1}}}{\sigma}\right)\right] P_{0}$.

The shareholder's expected equity is a function of asset mean and risk, although weights $1-\Phi$ and $\varphi$ themselves depend on these very factors as well as on the debt principal. We shall refer to the corresponding change in shareholder equity as her expected profit $\mu_{\mathrm{sh}}=$ $\bar{E}_{1}-E_{0}$, that is

$$
\mu_{s h}=\left[1-\Phi\left(\frac{P_{0}-\overline{A_{1}}}{\sigma}\right)\right] \overline{A_{1}}+\varphi\left(\frac{P_{0}-\overline{A_{1}}}{\sigma}\right) \sigma-\left[1-\Phi\left(\frac{P_{0}-\overline{A_{1}}}{\sigma}\right)\right] P_{0}-E_{0}
$$

This formal statement of shareholder profit suggests a few important points about how a shareholder is likely to view a firm's potential projects. Note first that the profit a shareholder associates with any project portfolio is a weighted sum of the portfolio's expected social value - namely the overall asset value it is expected to generate - and its risk. It takes the form $\mu_{s h}=K \mu+\mathrm{J} \sigma$. Unlike the owner of an all-equity firm, who cares only about expected value, the shareholder in a hierarchically differentiated capital structure rationally thinks about the effect risk has on her profit. 
A few more words are in order. First, because $\varphi\left[\left(P_{0}-\bar{A}\right) / \sigma\right]$ is a probability of a standard normal variate, it is positive. Thus, in the presence of limited liability, greater portfolio risk always brings the shareholder greater expected profit. The size of this effect, and thus risk's potency in generating mean profit, rises as $P_{0}-\bar{A}$ falls toward zero because $\varphi$ is a maximum at that point. And because declining $P_{0}-\bar{A}$ equivalently boosts the firm's debt-to-asset ratio $P_{0} / \bar{A}$, the shareholder's incentive to adopt high-risk portfolios approaches its maximum when her equity $E_{0}=A_{0}-P_{0}$ approaches zero and the firm approaches insolvency.

Furthermore, greater portfolio risk $\sigma$ itself boosts risk's positive influence on expected profit because, provided expected assets exceed debt, rising $\sigma$ reduces $\left(P_{0}-\bar{A}\right) / \sigma$ and thus lifts $\varphi$. In sum, a risk-neutral shareholder will act as a risk-seeker in her common stock investments, and increasingly so as either the firm approaches insolvency or finds opportunities to invest in high-risk portfolios.

Not surprisingly, a rising expected value $\bar{A}$ of the firm's projects itself will boost the shareholder's mean return. That is, coefficient $1-$ $\Phi\left[\left(P_{0}-\bar{A}\right) / \sigma\right]$ of mean return $\bar{A}$ in equation (4) is the probability that the firm's assets at time 1 will be greater than $P_{0}$ - and this probability, although less than one, will always be positive. (Think of it as the probability that a liquidation at time 1 will generate cash for shareholders.) All else equal, in other words, shareholders prefer high over low expected-value portfolios in addition to high-risk ones. Shareholders will seek to maximize the expected value of the firm's assets for any fixed amount of risk. They will always prefer that assets be efficiently used, pushing the firm toward opportunities on its expected value-variance frontier. In sum, shareholders prefer a high-value project over a low-value project, and they prefer a risky venture to a safe one, at a relative rate that depends on the firm's distance from insolvency and on the portfolio risk itself.

Until now we have been discussing shareholders' wishes. We need also to consider the firm's opportunities, that is, the way $\bar{A}$ and $\sigma$ trade off in the marketplace. Economic theory tells us that on the firm's market frontier, the expected value of available projects is related to their risk. A risk-neutral investor seeks opportunities which maximize expected value, whatever their variance. By definition, a risk-seeking (risk-averse) investor is one who is willing to accept lower expected value in order to increase (decrease) variance.

The tradeoff between expected value and risk that shareholders prefer is the tradeoff that maximizes their expected profit. Mathematically inclined readers will see immediately that the 
mechanism by which shareholders best exploit the risk-expected value tradeoff available to them in the market lies in the coefficients in equation (4). The coefficients indicate that a shareholder will become increasingly insensitive to risk-will increasingly seek expected value relative to risk-as expected assets increase relative to debt owed. To see this, hold everything in equation (4) constant except assets. Imagine assets growing large relative to principal owed. As assets relative to principal increases, $P_{0}-A_{1}$ takes on a large negative value. This value lies in the left tail, so to speak, of the probability distribution. The cumulative probability of such an outlier goes to zero as assets go to infinity, and consequently the coefficient of the expected-value term goes to one. At the same time, the coefficient of the risk term goes to zero. In other words, the social expected-value term increasingly dominates the shareholders' profit equation as the firm's debt-to-assets ratio falls. The intuition is straightforward. A firm with a small debt-to-assets ratio approaches the all-equity or single-owner firm described above. And recall that shareholders in an all-equity firm care only about the expected value of the firm's projects. As the debt-to-assets ratio increases, on the other hand, the coefficient of the expected-value term diminishes and the coefficient of the risk term increases. In descriptive terms, the impact of risk on the shareholders' profit equation increases as the firm's expected debt-to-assets ratio increases. The greater the firm's debt-to-assets ratio, the more a shareholder will be expected to agitate for risk at the expense of expected value.

We can derive the expected value of a creditor's interest $\left(P_{1}\right)$ and expected profit $\left(\mu_{\mathrm{cr}}\right)$ in a similar fashion. Here the starting point is twofold: (1) the creditor's maximum recovery is $P_{0}$, which he receives whenever $A_{1} \geq P_{0}$, and (2) the creditor receives $A_{1}$ whenever $A_{1}<P_{0}$.

(6) $P_{1}=\left[\begin{array}{ccc}P_{0} & \text { if } & A_{1} \geq P_{0} \\ A_{1} & \text { if } & A_{1}<P_{0}\end{array}\right]$.

If at time 0 the firm is solvent, then it is helpful to think of the interval between time 0 and time 1 as exposing the creditor to losses only. Creditor's "profit" equation takes on a strictly negative (or zero) value. In the interest of conserving paper and time, I give the creditor's profit equation as follows:

(7) $\mu_{c r}=\Phi\left(\frac{P_{0}-\overline{A_{1}}}{\sigma}\right) \overline{A_{1}}-\varphi\left(\frac{P_{0}-\overline{A_{1}}}{\sigma}\right) \sigma+\left[1-\Phi\left(\frac{P_{0}-\overline{A_{1}}}{\sigma}\right)\right] P_{0}-P_{0}$. 
Like shareholders, a creditor will always prefer high expected-value projects over low-value projects, all else equal. To understand the intuition at play, think of a high expected-value project as shifting the distribution of possible assets at time 1 to the right. Holding risk constant, boosting a project's expected value will reduce the cumulative probability that assets at time 1 will be less than $P_{0}$. That is, the higher the project's mean return, the greater is the likelihood that the firm will have assets sufficient to pay off the creditor in full.

Unlike shareholders, though, a creditor dislikes risk. In fact, a positive change in risk decreases a creditor's expected recovery by precisely the amount it increases shareholders' expected profit. Risk alteration has zero-sum consequences. ${ }^{24}$ Holding all else constant, increasing the variance of a firm's performance decreases the creditor's expected recovery. Creditors prefer high-value, low-risk projects. But as in the case of the shareholder, the creditor seeking to maximize his expected profit must trade off between expected value and risk among projects available in the market. When the firm is highly solvent, the expected-value term dominates the creditor's profit equation-just as it does for, and for the same reasons as in, the shareholder's profit equation. But as the firm's expected debt-to-assets ratio increases, so does the relative importance of risk in the creditor's profit. As the firm approaches insolvency, a creditor is increasingly willing to trade highvalue for low-risk projects.

Modeling shareholder and creditor payouts as we have reveals some important points about vertical investor conflict. First, the presence of conflict between vertically differentiated investors does not depend on differences in their risk tolerances. The model above assumes that each investor is risk neutral. It shows that a risk-neutral shareholder will appear risk-seeking in the context of her investment in a limited-liability firm, and that a risk-neutral creditor will appear risk-averse in the context of his investment in the same firm. Nor does a conflict necessarily turn on differing estimates of projects' expected balance-

24. This is not strictly true if only the firm's creditors at time 0 are taken into account. Because limited liability protects existing creditors from reprisal by future creditors in the same way it protects shareholders, increasing risk can in extreme cases generate a positive sum for investors at time 0 . Think, for example, of a firm that at time 0 considers moving into the chemicals industry, taking on potentially massive environmental liability. I set aside this possibility here in order to focus on the typical case. For an argument that the problem is smaller than scholars have suggested (and for a thoughtful discussion of the related literature), see Yair Listokin, Is Secured Debt Used to Redistribute Value from Tort Claimants in Bankruptcy? An Empirical Analysis, 57 DuKE L.J. 1037, 1038-46 (2008). 
sheet effect or risk. Our model has assumed that each investor knows (or at least agrees on) the firm's debt-to-assets ratio at time 0 , as well as the expected value of and risk associated with the firm's possible projects. The investors' differing rights in the firm, apart from their private characteristics, causes vertical investor conflict.

Second, the magnitude of vertical investor conflict depends on the firm's debt-to-assets ratio. Shareholder and creditor interests are never perfectly aligned. Shareholders always display some risk-seeking tendency and creditors always appear risk-averse. But when the firm is highly solvent - when, that is, assets are large relative to debt-the conflict practically disappears. When the firm is highly solvent, the expected value of the firm's projects dominate the profit equations of shareholder and creditor alike. As the debt-to-assets ratio goes to zero, the vertically differentiated investors' unity becomes perfect and seeks asset-value-maximizing projects. Investors in such a firm will agree on how the firm should operate, subject only to the caveat that a creditor and shareholder, like any two shareholders or any two creditors, might disagree about which ventures in particular are likely to maximize expected asset value. As the firm approaches insolvency, on the other hand, shareholders and creditors become increasingly risk-sensitive. Both classes of investor increasingly care about the risk rather than the expected balance-sheet effect of the firm's projects. ${ }^{25}$

Another way to think of the dynamic is to start by considering the expected (social) value of a firm's potential projects. When a firm is highly solvent - or, to take the extreme case, when all of the claims against a firm's assets are in the hands of a single investor - the expected social value of the firm's available projects dominates the investors' private profit identities. What is best in expectation for the firm's balance sheet is also best for the investors' pocketbooks. But as the firm's debt-to-assets ratio increases, the risk associated with available projects takes on increasing importance to the investors. As we saw in the hypothetical above, both shareholder and creditor will wish the firm to forego the projects with the greatest social value-although their reasons for doing so and the direction in which they push the firm will be strictly opposed. Neither shareholder nor creditor will seek the social

25. This analysis of course assumes that the firm's capital structure is fixed. As we shall see, the prospect of restructuring, including the outright unification of the capital structure through buyout, may temper investors' apparent deviation from risk neutrality. Indeed, in a world without transaction costs the existence of possible restructuring would eliminate vertical investor conflict entirely. 
optimum.

\section{B. Managerial Incentives under Conditions of Conflict}

At first blush, managers rather than shareholders or creditors decide how to deploy a firm's assets. Understanding how managers are likely to react to vertical investor conflict absent legal intervention is thus crucial to an evaluation of law's domain. How do managers act in the face of vertical investor conflict? Whom do they favor, if anyone? At first approximation, it is fair to say that a person works for those who can fire her. In a healthy firm, shareholders ultimately hold the right to fire, and one can conveniently think of management as their (imperfect) agents. But there is a competing and equally apt maxim: one's boss tomorrow is one's boss today. Lame ducks command little allegiance. A manager who believes that someone other than today's shareholders will hold the whip hand tomorrow tries to satisfy the heir apparent. This section explores the manager-investor dynamic in financially distressed firms. It aims to show that managerial reaction to vertical investor conflict is ambiguous. Theory cannot tell us much about the risk tolerance managers will exhibit - whether, in other words, they will tend to favor shareholders or creditors. Managers are likely to seek projects entailing more risk than creditors want but less than shareholders do. This ambiguity has important consequences. Among other things, it means that third-party observers, courts among them, lack a stable presumption about the kind of projects the manager of a distressed firm is likely to choose. Investor dissatisfaction can serve at best as a weak signal of deviation from a legal norm (unless the legal rule is that managers should always act in the interest of one or another constituency).

On the traditional view of corporate governance, managers are thought to be aligned principally with a firm's shareholders. Directors serve at the mercy of the shareholders' vote; officers serve at the board's. Although ousters are rare in public companies, the mere threat of a proxy fight or takeover attempt disciplines managers who might otherwise ignore dispersed shareholders. Similarly, managers often hold, and are expected to hold, a significant equity stake in the firms they manage, aligning incentives. This is not to say that theorists of the firm have understood managers as faithful agents. That idea was long ago discredited, and an extensive agency-cost literature describes the tendency of a firm's managers to shirk responsibilities, consume 
excessive perquisites, or otherwise self-deal. ${ }^{26}$ But the accepted view has been that, in a choice between shareholders and creditors, the manager would, and perhaps should, naturally support the shareholders. ${ }^{27}$

Recent scholarship has questioned the conventional wisdom, focusing on the power of creditors, especially senior bank lenders, to influence management's investment decisions. ${ }^{28}$ Most directly, a lender might control the firm's risk profile through covenants restricting capital expenditures or fundamental changes to the firm's business model. ${ }^{29}$ Because risk alteration often depends on significant outlays, as for example when a firm wishes to enter a new line of business, the veto associated with these covenants is for better or worse a powerful check on shareholder preferences.

Covenants facially having nothing to do with investment policy offer creditors a subtler, yet equally important lever to influence manager behavior. $^{30}$ A typical bank loan includes manifold covenants. ${ }^{31}$ Some relate to the firm's financial condition. For example, the debtor may covenant that the ratio of its earnings to outstanding debt will remain above an agreed threshold. ${ }^{32}$ Other ubiquitous covenants relate only

26. See generally Adolph A. Berle \& Gardiner C. Means, The Modern Corporation AND PRIVATE PROPERTY 220-32 (1932) (discussing the social expectations and legal rules impacting managerial behavior); see also Jensen \& Meckling, supra note 20, at 312-13 (comparing the incentives and behavior of an owner-manager to that of a manager of a firm owned by outside investors).

27. See Frederick Tung, Leverage in the Board Room: The Unsung Influence of Private Lenders in Corporate Governance, 57 UCLA L. REV. 115, 123-25 (2009) (describing the conventional wisdom); see also George G. Triantis \& Ronald J. Daniels, The Role of Debt in Interactive Corporate Governance, 83 CALIF. L. REV. 1073, 1076-77 (1995).

28. Kenneth M. Ayotte \& Edward R. Morrison, Creditor Control and Conflict in Chapter 11, 1 J. LeG. ANALYSIS 511, 538-39 (2009); Douglas G. Baird \& Robert K. Rasmussen, Private Debt and the Missing Lever of Corporate Governance, 154 U. PA. L. REV. 1209, 1251 (2006); Triantis \& Daniels, supra note 27, at 1082-91; Tung, supra note 27, at 125-35. Financial economists began considering creditor influence somewhat earlier. See, e.g., Greg Nini, David C. Smith \& Amir Sufi, Creditor Control Rights and Firm Investment Policy, 92 J. FIN. ECON. 400 (2009); Clifford W. Smith Jr. \& Jerold B. Warner, On Financial Contracting: An Analysis of Bond Covenants, 7 J. FIN. ECON. 117 (1979).

29. A recent study finds that roughly 25 percent of public corporations have a bank loan agreement with a capital expenditure restriction. Nini et al., supra note 28 , at 405 .

30. Frederick Tung offers a thoughtful account of this form of creditor influence. See Tung, supra note 27, at 140-59. He finds that "covenant violations are common, even among well-run companies." Id. at 134. See also Baird \& Rasmussen, supra note 28, at 1227-36 (discussing the evolving law permitting lenders to have increasing control over major corporations through strict covenants).

31. For a sampling of the kinds of covenants often accompanying bank debt, see THE LSTA's COMPLETE CREDIT AGREEMENT GUIDE (Richard Wright, et al., eds.) 281-389 (2009).

32. For examples of common financial covenants, see $i d$. at 293-310. 
indirectly to the firm's financial health: the promise to maintain appropriate insurance, for example, or to furnish data concerning the firm's business. ${ }^{33}$ The violation of any covenant typically empowers the lender to call its loan due immediately. This right provides considerable leverage. If the debt owed to creditor $C$ is large relative to the firm's liquid asset base, a decision by $C$ to accelerate his loan's maturity can effectively force the firm into Chapter 11. Formal reorganization is costly, and especially so for the officers of a corporate debtor, most of whom can expect to be shown the door. ${ }^{34}$ A CEO who values her job, or who values a soft landing after dismissal, is therefore inclined to listen carefully to a creditor's advice after a covenant violation. And the same is true even before a firm trips the control wire by violating a covenant. The manager of a distressed firm knows only too well that a technical default lurks around the corner; that the firm's ability to satisfy its covenants will turn to some degree on fortune. The manager thus weighs her options with bankruptcy looming in the shadow. ${ }^{35}$

It is not just that creditors, as a class, have leverage comparable to that of shareholders, as a class. Creditors may also be more adept at using it. The power to enforce loan covenants typically rests with a single bank or a small syndicate of lenders. According to one theory of capital structure, this concentrated interest among the senior creditors is vital to efficient monitoring of management slack. ${ }^{36}$ The power to fire directors and, indirectly, senior executives, on the other hand, is widely dispersed among shareholders. Thus, the concentration of interest that makes a good monitor also makes a good user of leverage.

A manager set on keeping her job faces an ambiguous landscape. We have seen that as a firm moves toward insolvency, its shareholders and creditors alike will agitate for risk alteration. Shareholders might fire the manager if, from their perspective, her investment decisions are too risk-averse. Yet by pursuing a relatively risk-seeking strategy (to pacify shareholders), the manager exposes herself to the possibility that a vigilant creditor will invoke a covenant default to oust her; and, of

33. Id.

34. See Ayotte \& Morrison, supra note 28, at 512-20 (finding that 70 percent of CEOs are replaced within the two years following the bankruptcy filing).

35. See Baird \& Rasmussen, supra note 28, at 1209-11 (connecting the firing of Krispy Kreme's CEO, outside formal bankruptcy proceedings, to the implied threat of creditor action).

36. Saul Levmore, Monitors and Freeriders in Commercial and Corporate Settings, 92 YALE L.J. 49, 57-59 (1982) (explaining that for a lender to have the proper incentives to monitor, it has to enjoy the benefits of monitoring). 
course, it is precisely when the firm is financially distressed that covenant default is most likely. How the manager gauges the investors' relative power will turn on particulars: the relative concentration of interest in the investor classes, the nature of the covenants in place (especially the perceived likelihood of a default), and even the personalities of key investors.

The manager faces a dilemma whatever her assessment of these factors. Multiple strategies are plausible. Suppose, for example, the manager thinks shareholder and bank power is in equipoise. She thinks that at future time $t$ there is a fifty percent chance that the bank will effectively have the firing power. One strategy would be to pursue a middle path, a risk-neutral investment strategy. The manager pursuing this strategy hopes that her decision will not anger either constituency too much. She may be disappointed to learn, however, that she angered both. Each constituency has another manager in mind. Depending on the situation, then, the manager might decide to cast her lots with one or another constituency.

A self-interested manager's regard for her job is of course only one factor determining her optimal strategy. It is hard to imagine an executive who is not also a passive investor in the firm she manages. The firm's operations are bound to have wealth effects on these investments. Here again, though, the net effect on the manager's apparent risk tolerance is a question about which little in the abstract can be said. Most managers - most officers, anyway-hold common stock. Employment agreements often mandate it. As a stockholder, the manager will tend to favor a risk-seeking investment strategy. But managers often hold debt or claims against the firm with debt-like characteristics. $^{37}$ As a creditor (or quasi-creditor), the manager will tend to favor a risk-averse investment strategy.

One can think of a self-interested manager as choosing investment strategies that promise to maximize the expected value of her own, private wealth identity. The manager derives wealth from passive shareholding, passive debt holding, and from employment (in the form of salary and perquisites), the last of which itself depends on satisfying both shareholders and creditors. Thus, the manager's profit equation is a

37. Defined-benefit pension interests are effectively debt. A deferred compensation plan is another example. Deferred compensation promises the manager a fixed payment (similar to the face value of a bond) at a future, specified date (similar to a maturity date). The manager faces downside risk but has no upside. 
weighted average of the shareholder and creditor profit equations. In the language of the model above, the self-interested manager seeks to maximize the following equation:

(8) $\mu_{m a}=\propto \mu_{s h}+(1-\propto) \mu_{c r}^{38}$

where the coefficient $\propto$ is the weight accorded to shareholder interests.

The manager's apparent risk tolerance turns on the relative weight she is likely to give to the interests of each investor class. In the extreme case it will be relatively easy to figure out. Imagine a self-interested manager who works for a salary of $\$ 1$ per year and values the perquisites of office at $\$ 0$. If she owns $\$ 1$ million of stock and holds no debt-like interests, then she will exhibit the risk-seeking tendency associated with the shareholders. And likewise she will pursue a risk-averse strategy if the $\$ 1$ million is tied up in a deferred compensation plan. ${ }^{39}$ In the run-ofthe-mill case, though, the puzzle is intractable. The typical manager holds a combination of equity and debt-like interests, perhaps weighted toward equity. ${ }^{40}$ But she also enjoys the financial and other privileges of tenure. It might be possible to determine a manager's optimal strategy if one had complete information, including knowledge of the manager's subjective assessment of the firm's prospects and its investors' idiosyncratic characteristics. On that I am agnostic. The thesis here is less ambitious. It is that in most cases where a firm faces financial distress, theory furnishes little predictive power about the kind of investment strategies the firm's management will be inclined to pursue absent the threat of legal intervention.

This ambiguity is of central concern when thinking about how legal

38. I have assumed throughout that the firm's investors are privately risk-neutral. There may be reason to doubt whether the assumption is a plausible one for executive officers. A rich literature of executive compensation assumes that executives, unable fully to diversify their investment in the firm, will exhibit risk-averse tendencies. See Joseph G. Haubrich, Risk Aversion, Performance Pay, and the Principal-Agent Problem, 102 J. POL. ECON. 258, 267 (1994). On the other hand, some studies suggest that corporate executives, like politicians, are risk seekers across a number of domains. See Daniel Kahneman \& Dan Lovallo, Timid Choices and Bold Forecasts: A Cognitive Perspective on Risk Taking, 39 MGMT. SCI. 17, 18 (1993) ("[S]tudies of individual choice have shown that managers, like other people, are risk-seeking in the domain of losses.").

39. Even in this unlikely hypothetical, the manager's strategy is perhaps uncertain. To the extent manager $A$ 's decisions can be reversed by a subsequent manager $B$ - after $A$ has been fired - a strategy of partial appeasement could be optimal.

40. See M. Todd Henderson, Paying CEOs in Bankruptcy: Executive Compensation when Agency Costs Are Low, 101 Nw. U. L. REv. 1543, 1548-57 (2007) (reporting that in public companies, up to half of CEO compensation is in the form of equity). 
rules might encourage managers to seek the social good, a question to which Part IV is addressed. It is worth pausing here, however, to note that the manager most likely to maximize a firm's value is the manager who weighs the interests of investor classes equally. This manager has the following profit identity:

(9) $\mu_{m a}=.5 \mu_{s h}+.5 \mu_{c r}$.

Substituting equations (5) and (6) for the shareholder and creditor profit identities, respectively, yields the following equation after cross multiplying and modestly simplifying:

$$
\begin{gathered}
\mu_{m a}=.5\left[1-\Phi\left(\frac{P_{0}-\overline{A_{1}}}{\sigma}\right)\right] \overline{A_{1}}+.5\left[\Phi\left(\frac{P_{0}-\overline{A_{1}}}{\sigma}\right) \overline{A_{1}}\right]-.5\left(E_{0}-P_{0}\right) \\
=.5 \overline{A_{1}}-.5\left(E_{0}-P_{0}\right) \\
=.5\left[\left(A_{0}+\mu\right)-.5\left[\left(A_{0}-P_{0}\right)-P_{0}\right]\right.
\end{gathered}
$$

because $\overline{A_{1}}=A_{0}+\mu$ and $E_{0}=A_{0}-P_{0}$. Simplifying reveals a profit equation in which risk plays no part:

(11) $\mu_{m a}=\frac{\mu}{2}$.

A manager who weighs shareholder and creditor interests equally acts risk neutrally. She maximizes her expected profit by maximizing the social value of the firm's projects.

\section{VALUE MAXIMIZATION AS A LEGAL IDEAL}

In a laissez faire world, management resolution of vertical investor conflict is ambiguous. The value of legal intervention, then, depends in the first instance on the ideal the law seeks. This is clear enough. Every legal intervention generates costs, and its utility therefore turns on the degree to which it encourages social behavior. Suppose, for example, that in the face of vertical investor conflict the law wants managers to use corporate assets for their own interests first and foremost, subject to 
explicit limitations imposed by statute or contract. ${ }^{41}$ It is hard to imagine a doctrine of intervention serving any purpose. Yet another rule may better achieve different resolution. The question in this Part is what norm, what ideal, of managerial behavior the law seeks when the interests of a firm's investors conflict. It argues that our law asks managers to maximize the value of firm assets to investors as a group, and that the law does so through the synthesis of the fiduciary duty of loyalty (owed to shareholders) and fraudulent transfer principles (owed to creditors).

It will be helpful to note at the outset that the managerial problem arises only because of incomplete contracting. ${ }^{42}$ To the extent explicit investment contracts direct the manager to do one thing or another, ordinary contract principles furnish easy answers. And as we have seen, a variety of explicit promises typically restrict managerial freedom in the modern business organization. ${ }^{43}$ Yet inevitably managers enjoy a residue of discretion, sometimes more and sometimes less. Expert judgment in the use of this residual authority justifies managerial salaries, and without residual authority there would be no need for incentive-based payments. Managers could be paid like administrators. That, of course, is not our world. Managers in fact enjoy wide latitude in their deployment of firm assets. The concern here is the standard of judgment by which managers should exercise whatever residual discretion they hold.

There is a large body of literature-statutory, judicial, and scholarly - on this most important question of corporate governance. Courts and scholars have generally assumed that the answer lies in the definition of the fiduciary duty of loyalty, and this Part begins with a brief survey and evaluation of the conclusions they have reached. Traditionally, fiduciary duties have been understood to run in favor of shareholders and shareholders only, suggesting that a manager is permitted, even obliged, to ignore creditor interests (including suppliers, employees, and other creditor-like constituencies). This Part then argues that singular focus on fiduciary duty is misguided. Debtor-creditor law has much to say about managerial norms. In particular, this Part argues,

41. Cf. Baird \& Henderson, supra note 9, at 1315-16 (arguing that no residual legal duty ought to run from managers to their firms or investors, but rather that they "should merely be obliged to honor the terms of the firm's investment contracts, even when they lead to decisions that are not value-maximizing ex post for the investors as a group").

42. See EASTERBROOK \& FISCHEL, supra note 19, at 90-108.

43. See supra Part II.B. 
fraudulent transfer principles suggest that a value-maximization norm underlies existing law.

\section{A. Competing Visions of the Duty of Loyalty}

The traditional understanding of fiduciary duty is well illustrated by the canonical case of Dodge v. Ford Motor Co. ${ }^{44}$ The case turned on Henry Ford's plan to reinvest Ford Motor Company's profits in additional factories rather than pay a special dividend to the firm's shareholders. Whether expansion would ultimately benefit the shareholders was not Ford's main concern. He explained that under his direction Ford's mission would be to provide work and inexpensive cars to an undifferentiated labor class that had no legal claim on the company's assets. In the suit brought by objecting shareholders, the court held that Ford's plan was inconsistent with his fiduciary obligation. The manager could not seek to enrich outsiders at the expense of shareholders. ${ }^{45}$

The managerial ideal described in Dodge and similar cases is that of shareholder-wealth maximization. ${ }^{46}$ Not every decided case is consistent with the rule, of course, ${ }^{47}$ but it is a fair approximation to say that shareholder-wealth maximization has been the traditional, direct aim of the duty of loyalty. ${ }^{48}$ Dodge pitted the interests of shareholders against the interests of a generalized labor force or class of society; it did not specifically address the conflict between vertically differentiated investors. ${ }^{49}$ But a number of cases out of Delaware and other important

44. 170 N.W. 668 (Mich. 1919).

45. For a detailed account and competing interpretation of Dodge, see M. Todd Henderson, Everything Old Is New Again: Lessons from Dodge v. Ford Motor Co., University of Chicago Law \& Economics, Olin Working Paper No. 373 (2007), available at http://www.law.uchicago.edu/files/files/373.pdf.

46. See Dodge, 170 N.W. at 681-82.

47. See Shlensky v. Wrigley, 237 N.E.2d 776 (Ill. App. Ct. 1968) (dismissing derivative suit in which shareholders claimed directors acted negligently by failing to install lights at Wrigley Field in order to hold profitable weekday night games). Shlensky undoubtedly represents a minority view. It may be best understood as a decision anticipating nuisance liability or proto-liability.

48. See Frederick Tung, Gap Filling in the Zone of Insolvency, 1 J. Bus. \& TECH. L. 607, 609 (2007) [hereinafter Tung, Insolvency] ("Under the well-known shareholder primacy rubric-long dominant among courts and commentators-directors' fiduciary duties run exclusively in favor of the corporation's common shareholders, and duty requires the board to maximize shareholder returns."); E. Norman Veasey \& Christine T. Di Guglielmo, How Many Masters Can a Director Serve? A Look at the Tensions Facing Constituency Directors, 63 Bus. LAW. 761, 766 (2008) ("[I]n Delaware, the directors' duties to stockholders must trump their concerns for other constituencies.").

49. See Dodge, 170 N.W. at 670-71. 
States have subsequently made the connection explicit. ${ }^{50}$ On the traditional view, managers deciding how to employ firm assets ought to privilege the common shareholders over competing constituencies.

In 1991, Delaware's Court of Chancery took up the question of vertical investor conflict explicitly in Credit Lyonnais. ${ }^{51}$ As in Dodge, the plaintiffs in Credit Lyonnais alleged that management had violated its duty of loyalty by choosing a course of action that preferred a constituency (creditors, in this case) over shareholders. ${ }^{52}$ Chancellor Allen refused to intervene, holding that when a firm is in the vicinity of insolvency, creditors are a part of the "community of interests" that managers can and should consider. ${ }^{53}$ The decision appeared to create a regime in which the direction of fiduciary duties shifts with the degree of a firm's solvency.

Even before, but especially in the years following Credit Lyonnais, scholars have posed a variety of normative criticisms of Delaware fiduciary duty doctrine. One branch of criticism has defended a shareholder-wealth maximization principle on normative grounds. ${ }^{54}$ Reasons have varied. Some commentators have advanced a quasimetaphysical argument that equity holders, unlike other investors, "own" the firm in some intangible sense. ${ }^{55}$ Others have argued that the

50. E.g., Simons v. Cogan, 549 A.2d 300, 303 (Del. 1988) (“[A] convertible debenture represents a contractual entitlement to the repayment of a debt and does not represent an equitable interest in the issuing corporation necessary for the imposition of a trust relationship with concomitant fiduciary duties."); see also 7 COLLIER ON BANKRUPTCY II 1108.10 (Alan N. Resnick \& Henry J. Sommer eds., 16th ed. 2012) ("Outside of bankruptcy, the traditional rule is that so long as a corporation is solvent, the obligations of its officers and directors, including the duties of care and loyalty, run to stockholders, not creditors.").

51. Credit Lyonnais Bank Nederland, N.V. v. Pathe Commc'ns Corp., No. Civ.A.12150, 1991 WL 277613 (Del. Ch. Dec. 30, 1991).

52. Id. at $* 1154$.

53. Id. at *1155-57.

54. See Bainbridge, Defense, supra note 6, at 1446-47 (asserting that a rule favoring shareholder interests "has helped produce an economy that is dominated by public corporations, which in turn has produced the highest standard of living of any society in the history of the world"); Stephen M. Bainbridge, Director Primacy: The Means and Ends of Corporate Governance, 97 Nw. U. L. REV. 547, 605-06 (2003) (arguing that director primacy in decision-making can be reconciled with shareholder wealth-maximization); Stephen M. Bainbridge, Much Ado about Little? Directors' Fiduciary Duties in the Vicinity of Insolvency, 1 J. BuS. \& TECH. L. 335, 355 (2007) [hereinafter Bainbridge, Much Ado] (arguing that traditional allegiance to shareholders is preferred because responsibility to a larger constituency leads directors to primarily pursue self-interest); $\mathrm{Hu} \&$ Westbrook, supra note 6, at 1402-03 (calling for abolition of duty-shifting doctrine); Tung, Insolvency, supra note 48, at 625-26 (arguing that extending fiduciary duties to creditors, at least to sophisticated bank lenders, would be counterproductive).

55. Hu \& Westbrook, supra note 6, at 1323. 
shareholder-wealth maximization is a contractual term that should be honored like any other. ${ }^{56}$ Still others have argued on efficiency grounds or for psychological reasons that managers should exercise their discretion exclusively for the benefit of shareholders. ${ }^{57}$

Another branch of criticism has sought a norm antithetical to the traditional, shareholder-centered norm. Recognizing that risk-shifting threatens appropriation by shareholders of creditor wealth, and that the risk of appropriation increases the cost of raising capital through debt, commentators in this vein have argued for a strong rule of creditor protection. In short, they argue that managers should pursue shareholder welfare through increasing the risk of corporate projects only when doing so would not diminish expected creditor recoveries - only when, in other words, increasing risk is Pareto optimal among the firm's investors. ${ }^{58}$

Yet, another school favors managers over either shareholder or creditor constituencies. In a recent article, Douglas Baird and Todd Henderson argued that courts should forget about fiduciary duty altogether. $^{59}$ Managers must honor explicit contracts, they argue, but courts should be out of the business of second-guessing decisions by reference to the implicit contract known as fiduciary duty. ${ }^{60}$ In practical terms, this argument amounts to a rule that managers should do what benefits them within the limits of explicit contracts. ${ }^{61}$ In the language of Part II, the manager is justified in maximizing her own profit equation rather than the expected profits of any other constituency or constituencies. ${ }^{62}$

In another light, this pro-management approach can be understood as

56. Bainbridge, Much Ado, supra note 54, at 337.

57. Viral V. Acharya, Yakov Amihud \& Lubomir Litov, Creditor Rights and Corporate RiskTaking, 102 J. FIN. ECON. 150, 152 (2011) (proposing that strong creditors' rights in default may lead to inefficient liquidation and hurt shareholder value); Bainbridge, Defense, supra note 6, at 1427 (discussing Milton Friedman's assertion that managers steal from shareholders when placing non-shareholder interests above equity interests); Tung, Insolvency, supra note 48, at 609 (claiming that sophisticated creditors can more efficiently control manager behavior by contract, rather than through the judicial system).

58. E.g., McDaniel, Corporate Governance, supra note 7, at 449-50 (1986); McDaniel, Stockholders, supra note 7, at 222 (1988). McDaniel argues on behalf of bondholders in particular, but his argument seems to apply with equal force to creditors in general. See also David Millon, Redefining Corporate Law, 24 IND. L. REv. 223, 226 (1991) (exploring the implications of directorduty statutes that expand directors' obligations to non-shareholders).

59. Baird \& Henderson, supra note 9, at 1315-16.

60. Id. at $1327-28$.

61. See id. (arguing for a rule that imposes on managers a fiduciary duty to the corporation as a whole through a "contractarian" approach).

62. See id. 
stating an argument about the deficits of judicial intervention rather than about the ideal toward which law would have managers strive. ${ }^{63}$ And in this sense Baird and Henderson are probably nearest the attitude of Delaware's courts. In decisions since Credit Lyonnais, its chancery and supreme courts have explained that the "shifting" managerial duties Chancellor Allen described are not meant to give creditors standing to challenge corporate decisions; they are rather a justification on which management can rely in defense to shareholder suit. Managers can invoke their fiduciary obligation to creditors as a shield against shareholder challenges; but creditors, lacking any definite weight of consideration, cannot use the obligation as a sword. ${ }^{64}$ The Credit Lyonnais doctrine represents skepticism about judges' ability to diagnose socially inefficient management. ${ }^{65}$

In any event, it should be clear that every conceivable constituency has at least an advocate or two among the academy. There are commentators who in turn would privilege shareholders, creditors, and managers. Yet the functional importance of the fiduciary rule is not immediately obvious. One can think of each competing rule as bestowing a property right on its favored constituency, namely the right to choose (or veto) corporate projects. The Coasean insight is clear: absent transaction costs, the choice of rule will not influence the ventures a hypothetical firm pursues. ${ }^{66}$

Imagine a firm presented with a possible new project. The project entails high risk and has negative expected social value. In expectation and relative to the status quo, it is worth $\$ 5$ to shareholders, $\$ 1$ to the manager, and will cause creditors to lose $\$ 10$. Irrespective of the constituency holding the property right, the firm operating in a frictionless world will not pursue the new project. If shareholders hold the right, creditors will pay between $\$ 6$ and $\$ 10$ to persuade the shareholders to forego it; likewise if the manager has the prerogative.

63. See id. at 1323 (stating that the business judgment rule is an "awkward tool for giving directors the legal guidance they need to make good decisions").

64. Prod. Res. Grp., L.L.C. v. NCT Grp., 863 A.2d 772, 790 n.57 (Del. Ch. 2004) (stating that the Court would be loath to choose between plausibly risky (pro-shareholder) and safe (pro-creditor) strategies); see also N. Am. Catholic Edu. Programming Found., Inc. v. Gheewalla, 930 A.2d 92, 99-101 (Del. 2007) (ratifying Prod. Res. Grp., L.L.C. v. NCT Grp., 863 A.2d 772 (Del. Ch. 2004)); Baird \& Henderson, supra note 9, at 1310-15.

65. See Prod. Res. Grp., L.L.C., 863 A.2d at 789-90.

66. The Coase Theorem can be stated as follows: if both parties know the rule of law when they act, the economic result is the same regardless of the legal outcome. Coltman v. Commissioner, 980 F.2d 1134, 1137 (7th Cir. 1992). 
And if creditors hold the right, then - unsurprisingly - they will decline the project because the $\$ 6$ that the shareholders and managers jointly would pay to pursue the project is less than the loss the creditors would expect to suffer. In any case, the firm will pursue the strategy that is socially optimal and that maximizes the expected returns of the investors as a whole. ${ }^{67}$

There is no frictionless world, of course. Transaction costs are likely to be relatively small in the context of a close firm, a point to which Part IV will return, but informational asymmetries between management and investors are chronic even where bargaining costs are low. Still, the thought experiment suggests another possible norm of management behavior in the face of vertical investor conflict-that the manager should pursue that course which maximizes the value of the firm's assets to the investors as a whole. One can think of the asset-valuemaximization norm as casting a veil of ignorance over corporate law. This is by no means a novel suggestion. Economists and legal scholars influenced by a contractarian approach to corporate law have lobbied in its favor for some time. ${ }^{68}$

An asset-value-maximization norm has much to commend it on normative grounds. Fundamentally, it directs assets to their socially optimal use. In contrast to proposals for a "shifting" norm, asset-value maximization also eliminates discontinuity in managerial responsibility. Vertical investor conflict is described by a continuous function. Discord increases continuously as a firm's debt-to-assets ratio grows. There is little reason to create a discontinuity and the attendant risk of strategic game-playing. To be sure, firms and their investors regularly agree to create discontinuities by contract, and some discontinuities turn on the firm's financial condition. Yet it is hard to fathom an argument for such contractual discontinuity if managers' good-faith application of an assetvalue-maximization norm can be assumed. Covenants creating discontinuity are, in other words, responses to perhaps rational fears that creditors will not have practical recourse against managerial infidelity.

A full-throated normative defense of asset-value maximization is

67. Because investment is contractual, the rule would not even have distributional consequences.

68. See, e.g., Smith, supra note 8, at 217-18 (arguing that rational investors engaged in a hypothetical bargain "would agree to a norm that told managers to maximize the value of the diversified portfolios that CAPM says rational investors would hold"). Baird and Henderson in fact describe this view as dominant among law-and-economics scholars. See Baird \& Henderson, supra note 9, at 1313-14. 
beyond this Article's scope. ${ }^{69}$ The purpose here is descriptive. Those who have championed an asset-value maximization norm have done so aspirationally, assuming uncritically that a change in state fiduciary law would need to instantiate the norm. The discussion below aims to show that myopic focus on fiduciary duty doctrine has clouded the debate over a more general managerial obligation and that, to put the point clearly, asset-value maximization is already the principle toward which our law seeks to direct managers.

\section{B. A Theory of Fraudulent Transfer}

This Part's central contention is that the principles of fraudulent transfer point in the direction of an existing asset-value maximization norm. The role of fraudulent transfer in corporate governance has been almost entirely neglected. Why this is so is something of a mystery. In part, it may be a result of historical classifications. The law of fiduciary obligation has always fallen under the rubric of a firm's "internal affairs."70 For corporations, the law of the firm's state of incorporation governs the scope and application of fiduciary duty; ${ }^{71}$ for partnerships, the law of the state in which the partnership is made. ${ }^{72}$ In particular, the courts of equity traditionally policed the boundaries of fiduciary obligation in the corporate context. Thus scholars and other thoughtful lawyers have overwhelmingly focused on the jurisprudence of the Delaware courts of chancery. ${ }^{73}$ Fraudulent transfer, on the other hand, developed first as part of the criminal law and, later, as an exception to general rules of property transfer and ownership. ${ }^{74}$ Courts have never understood fraudulent transfer claims as falling within the internal affairs

69. For a thorough defense, see Smith, supra note 8.

70. See 36 AM. JUR. 2D Foreign Corporations $\S 72$ (2013) ("The internal affairs doctrine applies to such matters as ... fiduciary obligations to the corporation ....").

71. Total Holdings USA, Inc. v. Curran Composites, Inc., 999 A.2d 873, 884 (Del. Ch. 2009) ("The internal affairs rule requires that the internal affairs of a corporation ... are governed by the law of the corporation's domicile.") (internal citation omitted).

72. $I d$.

73. See, e.g., Byron F. Egan, Fiduciary Duties of Corporate Directors and Officers in Texas, 43-SPG TEX. J. BuS. L. 45, 179 (2009) ("Given the extent of Delaware case law dealing with director fiduciary duties, it is certain, however, that Delaware cases will be cited and argued by corporate lawyers negotiating transactions and handling any subsequent litigation.").

74. See Jon Travis Powers, Fraudulent Transfer Liability Under the Uniform Fraudulent Transfer Act: For Statute of Limitations Purposes, Is Such Liability Grounded in Fraud or Created by Statute?, 20 J. BANKR. L. \& PRAC. 4 Art. 5 (2011) (explaining the origins of fraudulent transfer law in The Statute of Elizabeth, a penal statute). 
doctrine; the state in which the contested property is held has determined fraudulent transfer's domain.

Perhaps more importantly, fraudulent transfer has never received the theoretical attention that lawyers and scholars have lavished on the law of fiduciary duty. ${ }^{75}$ Since 1570 , every Anglo-American jurisdiction has prohibited debtors from transferring assets with the intent to "hinder, delay or defraud" creditors. ${ }^{76}$ Following the courts' lead, scholars have focused on describing and identifying "badges of fraud," evidentiary markers that a fraudulent transfer has occurred. ${ }^{77}$ Few have asked the fundamental question - what about a transfer makes it likely to "hinder, delay or defraud." What is it, in other words, that the badges of fraud are thought to signal? Without a theory of fraudulent transfer, it should be no surprise that scholars and lawyers have generally ignored the doctrine's implications for the norms of corporate governance. ${ }^{79}$ I suggest that attending to fraudulent transfer's meaning will, in particular, yield valuable information about the way in which managers are meant to resolve vertical investor conflict.

A theory of fraudulent transfer must start with Robert Clark, one of the few scholars who has sought to understand the theoretical principles

75. Robert Charles Clark, The Duties of the Corporate Debtor to Its Creditors, 90 HARV. L. REV. 505, 506 (1977) (asserting that identifying the purposes of fraudulent conveyance law is "a task sorely neglected in literally hundreds of cases applying that body of law").

76. The formulation dates to Parliament's enactment of a criminal sanction. 1570, 13 Eliz., c. 5 (Eng.). Every State in the United States has codified the prohibition through adoption either of the Uniform Fraudulent Conveyance Act $\S 7$ or its successor model statute, the Uniform Fraudulent Transfer Act $\S 4(\mathrm{a})$. John E. Sullivan III, Future Creditors and Fraudulent Transfers: When a Claimant Doesn't Have a Claim, When a Transfer Isn't a Transfer, When Fraud Doesn't Stay Fraudulent, and Other Important Limits to Fraudulent Transfers Law for the Asset Protection Planner, 22 Del. J. CoRP. L. 955, 1049 (1997). The Bankruptcy Code makes it federal law. 11 U.S.C. $\$ 548(\mathrm{a})(1)(\mathrm{A})(2012)$.

77. See Unif. Fraudulent Transfer ACt $\S 4$ (b), 7A U.L.A. 58, 59 (2006) (enumerating traditional badges of fraud). Responding to suits accompanying the rise of leveraged buyouts in the 1980s, a handful of scholars also began to consider the application of a relatively recent doctrinal development, the "constructive" fraudulent transfer. E.g., Kathryn V. Smyser, Going Private and Going Under: Leveraged Buyouts and the Fraudulent Conveyance Problem, 63 IND. L.J. 781, 792 (1988) ("[T]he constructive fraud provisions of the UFCA only apply to a limited category of debtor transactions which adversely affect creditors under certain circumstances of financial exigency."); Douglas G. Baird \& Thomas H. Jackson, Fraudulent Conveyance Law and Its Proper Domain, 38 VAND. L. REV. 829, 830 (1985) (describing an approach that "presumes mischief when an insolvent debtor voluntarily transferred property and got nothing or clearly too little in return").

78. UNIF. Fraudulent TRANSFER ACT $\S 4(a)(1), 7 A$ U.L.A. 378 (2006).

79. See Clark, supra note 75 , at 505 (noting, in the context of comparing fraudulent transfer with the doctrines of equitable subordination and veil piercing, "[t]he near absence of sustained discussion in cases or in the writings of commentators of the relationships among these branches of the law"). 
of fraudulent transfer law. ${ }^{80}$ From his broad survey of fraudulent transfer case law, Clark divined what he called four "normative ideals of fraudulent conveyance law": Truth, Respect, Evenhandedness, and Nonhindrance. ${ }^{81}$ Truth he explained as the principle that a debtor may not deceive his creditor in a manner that will lead to the impairment of the creditor's claims. ${ }^{82}$ This ideal is closely related to, or perhaps even identical with, the familiar common law understanding of frauddeceptive acts the reliance on which will tend to harm another. Thus a debtor may not lie about the assets he owns and which could be used to satisfy his debt in the event of nonpayment. This norm is without doubt a part of fraudulent transfer law. Indeed its connection with the traditional doctrine of fraud likely gave fraudulent transfer its name. Our investigation is not mainly concerned with a manager's deceptive acts, however, but rather with the kinds of dispositions a manager openly and honestly should choose. Similarly Clark's norm of Evenhandednessthat a debtor should not prefer one creditor over another when the debtor is nearly insolvent-is of little present interest, whatever its general validity as a principle of fraudulent transfer law. ${ }^{83}$

More important for present purposes are the ideals of Respect and Nonhindrance. Respect stands for the principle that a debtor must give "primacy" to the interests of contract and tort creditors, "as opposed to the interests of self, family, friends, shareholders, and shrewder or more powerful bargaining parties." 84 Nonhindrance is a "vague" ideal prohibiting acts which make the creditor's collection more difficult than it might otherwise be. ${ }^{85}$ In illustration, Clark says that Nonhindrance prohibits a debtor from converting liquid assets such as cash into illiquid assets more difficult to attach. ${ }^{86}$

Taken at their limit these ideals have radical implications. They would mean that a debtor is obliged to subordinate all affection for

80. $I d$.

81. Id. at 506. Apart from quoted material, I follow the National Conference of Commissioners of Uniform State Law in using "fraudulent transfer" in place of the older phrase, "fraudulent conveyance." See UnIF. Fraudulent Transfer Act, Prefatory Note. 7A U.L.A. 5 (2006).

82. Clark, supra note 75 , at 509 .

83. Id. at 512. Whether Evenhandedness is a real principle of debtor-creditor law is arguable. Modern preference law may be thought to embody it, but one suspects that preference law is designed primarily to ward off the threat of kickback. It is not necessary here to decide.

84. Id. at 510-11.

85. Id. at 513 .

86. Id. at 512-13. 
himself or his family or, critical to modern corporate cases, for shareholders, to the interests of the creditor. ${ }^{87}$ Surely, though, this is not what the law of fraudulent transfer demands. The question is in what kinds of situations a debtor must prefer his creditor over himself or other favored groups. To answer this question, a return to first principles will be profitable. Intuitions about base cases will do much to clarify the meaning of fraudulent transfer.

Start with a simple case. Suppose $A$ is a shepherd. He owns a flock of sheep worth $\$ 300$ and owes his creditor, $B, \$ 200$. Hoping to stiff $B, A$ decides to gift the sheep to his friend, $C$, leaving $A$ insolvent and unable fully to satisfy $B$ 's claim. $C$, not being in the business of animal husbandry and because of his fondness for $A$, allows $A$ to continue tending for the flock. When $B$ reduces his claim to judgment and directs the sheriff to levy on the sheep, $A$ and $C$ resist. They contend that the sheep do not belong to $A$ and therefore cannot be used to satisfy $B$ 's judgment. ${ }^{88}$

These facts present a clear-cut case of fraudulent transfer. $B$ will be permitted to avoid the transfer and take possession. All will agree on that. But what is the wrong? What about the gift hurts $B$ ? Ordinarily the owner of property may dispose of it as he pleases. Why not here? One view has it that the transfer is wrongful because it was secretly done. $A$ continued in possession of the sheep after divesting himself of ownership, making it look as though he continued to hold valuable assets. The problem is one of apparent ownership. Had he not been deceived, $B$ might have done more to protect the value of his claim. The transfer is improper because it violates Clark's ideal of Truth.

The elegant simplicity of this view has sowed a great deal of confusion and has led some to take a very narrow view of fraudulent transfer, making it merely a species of fraud or misrepresentation. ${ }^{89}$ But

87. Such a rule would replicate the norm of creditor privilege.

88. Students of debtor-creditor law will recognize this hypothetical as a slightly altered version of the facts of Twyne's Case, (1601) 76 Eng. Rep. 809 (Star Chamber), the fountainhead of fraudulent transfer law and the origin of the badges of fraud. On the reported facts of the real Twyne's Case, the transferee was not only a friend but also a creditor of the transferor, making the transfer an example of what today would be known as a voidable preference rather than a fraudulent transfer. $I d$ at 810 .

89. Hu \& Westbrook, supra note 6, at 1324 n.5 (arguing that corporate duties to creditors be limited to "constraints arising in contract and tort," and thus excluding "fraudulent behavior" from discussion). C.f. Brandon v. Anesthesia \& Pain Mgmt. Assocs., 419 F.3d 594, 600 (2005) ("The doctrine of 'fraudulent conveyance' has specific elements ... that differ from normal usages of the word 'fraud' ...."). 
in truth, the injury to $B$ has little to do with deception. To see this one need alter the facts only slightly. Assume that $B$ reduces his claim to judgment before $A$ gifts the flock to $C$. Assume even that $A$ notifies $B$ of the transfer and tells him that $B$ 's judgment is the very reason for the transfer. It matters not at all to $B$, who has his judgment in hand, whether $A$ 's gift is secret or notorious. A secret transfer might of course fool a potential subsequent lender, $D$, who naturally would gather that the sheep could be used to back any credit he might extend. But for $B$ that is neither here nor there. $B$ is upset only because the transfer has reduced the recovery he can expect to make on $A$ 's assets. A transfer need not be done in secret to be fraudulent.

It might be tempting, then, to say that a transfer "hinders, delays, or defrauds" a creditor if it reduces the creditor's expected recovery on his claim. Yet fraudulent transfer will not cover such a vast set of cases. Suppose a shepherd, $E$, who in all respects is identical to $A$ except that $E$ has $\$ 100$ in cash in addition to his flock. $E$ finds that he can use the cash to buy additional sheep. He reasonably believes that, between his expertise and economies of scale, he can turn the $\$ 100$ into sheep worth $\$ 110$. He also knows, of course, that sheep die-sometimes prematurely. Thus, there is a risk that his investment will evaporate. But disease is reasonably uncommon. $E$ estimates less than a one-in-ten chance that a plague will strike his flock. Taking the risk into account he expects a purchase to net $\$ 5$. As in the hypothetical above, however, the creditor $B$ is unhappy about the prospect of more sheep. If $E$ holds the $\$ 100$ in cash, $B$ is certain he will be able to satisfy a judgment if $E$ should fail to pay the interest due. But if $E$ converts legal tender into livestock, there is a ten percent chance the debt will be impaired. Just as in the prototypical case of fraudulent transfer, $E$ 's transfer - of cash, in this case-reduces $B$ 's expected recovery on his claim. The injury to $B$ is the same. ${ }^{90}$ Yet as the reader will predict, $E$ 's acquisition of sheep is not a fraudulent transfer. $^{91}$

This hypothetical suggests something that is missing from Clark's account of fraudulent transfer. According to Clark's ideal of Respect, and perhaps too that of Nonhindrance, $E$ 's purchase of additional sheep

90. The magnitude of the harm is less, but that is a consequence of the arbitrary numbers chosen to illustrate the cases.

91. Of course the purchase would be a breach of contract if $E$ had promised $B$ not to dispose of his cash in this manner. Covenants are enforceable. But to get to the root of the problem of how a debtor may exercise his residual discretion, we should assume that $B$ is a general creditor not owed any special right in this regard. 
ought to be condemned. ${ }^{92}$ Recall that Respect stands for the idea that a debtor must give primacy to the claims of creditors over his own interests or the interests of his family, friends, or objects of charity. ${ }^{93}$ According to Clark, then, $E$ should forget about buying sheep as soon as he realizes that to do so will reduce the value of $B$ 's claim against him. ${ }^{94}$ That is the meaning of primacy. One can see where the absolute nature of Clark's vision leads. If the creditor's interest is to be preferred to that of the debtor, then the debtor ought to do whatever he can to maximize the creditor's return, irrespective of the social costs (including the costs to himself). It is a rule under which debtors can engage only in Paretoefficient transactions. But fraudulent transfer requires no such thing. It does not give creditors veto power over all debtor transactions.

The distinction between these hypotheticals is the key to a credible theory of fraudulent transfer. It is a simple distinction and one which shows Clark to be near the truth. In both hypotheticals, the transfer reduced the value of $B$ 's claim against the debtor. The distinction is the expected effect of the transfers on the debtor's wealth relative to their expected effect on the creditor's wealth. In the case of the gift of sheep, the expected value of $A$ 's assets, to $A$, increased by an amount equal exactly to the expected impairment of $B$ 's interest. ${ }^{95}$ In the case of the sheep purchase, on the other hand, the expected value of $E$ 's assets, to $E$, increased by more than the diminution in value of $B$ 's claim.

The ideals of Respect and Nonhindrance must be restated. A debtor need not prefer his creditor to himself, but nor can he prefer himself unless by so doing he increases the aggregate value of his assets to both himself and his creditor. ${ }^{96}$ Put differently, a transfer "hinders, delays or defrauds" an existing creditor if and only if it will reduce his existing creditor's expected recovery without increasing the expected value to

92. Clark, supra note 75 , at 510-11.

93. Id.

94. Presumably Clark would permit $E$ to pay $B$ the amount by which he thinks acquiring the sheep would impair $B$, in expectation. In this sense Clark's rule comes very close to, or is even identical with, the proposals to forbid debtors from taking any action which would not be Pareto superior. Id.

95. This assumes that $A$ 's friend, $C$, will allow $A$ to exercise effective right over the sheepi.e., without paying rent. If $C$ were to charge rent, the increased value to $A$ of the sheep would be less than the decrease in their value to $B$.

96. See Clark, supra note 75, at 511 n.19 (analogizing the ideal of Respect to a corporate director's duty to "avoid abusive self-dealing and other conduct which puts his own interests, or that of a particular group of shareholders, above the interests of the shareholders as a whole"). 
himself and his creditor, combined, of the debtor's assets. ${ }^{97}$

One caveat regarding creditor expectations is in order. When a creditor implicitly or explicitly ratifies his debtor's transfer of assets, the transfer is not fraudulent against him. Suppose, for example, that our friend the shepherd is short on cash but sees an opportunity to turn a profit if only he could buy additional livestock. He turns to $B$ for a loan of the $\$ 50$ he needs to make the purchase and explains what he hopes to do with the proceeds. Now, however, the likelihood of disease is in some doubt. It may be that the purchase of additional sheep is a negative expected-value proposition. Buying the sheep, that is, might violate the rule just now stated-one cannot be sure. Nevertheless, $B$ will have no claim of fraudulent transfer. The reason is that he knew of the purchase before he extended the loan. ${ }^{98}$ To the extent $B$ believed it was a bad deal, he could have and should have - and probably did - charge an interest rate commensurate with the risk he saw in the enterprise. A rule permitting creditors to challenge known transactions would be perverse. $^{99}$

97. Development during the twentieth century of the rule of "constructive" fraudulent transfer should be understood as an attempt to catch those transfers most obviously designed to hinder, delay, or defraud creditors in the sense here described. Constructive fraudulent transfer prohibits the disposition of assets for less than reasonably equivalent value when the transferor is insolvent or nearly so. E.g., UNIF. FraUdULENT TRANSFER ACt § 5(a), 7A U.L.A. 129 (2006); See MSKP Oak Grove, LLC v. Venuto, 875 F. Supp. 2d 426, 438 (D.N.J. 2012) (showing how the judgment creditor properly alleged constructive fraudulent transfer under New Jersey Uniform Fraudulent Transfer Act based on corporation's distributions to shareholders near insolvency). The reader will recall the significance of the debtor's being near insolvency. It is when the debtor is financially strapped that he will be most inclined to pursue negative-value propositions that offer hope of a big payout. State laws prohibiting corporate distributions to shareholders in similar circumstances serve the same purpose. See, e.g., DEL. CODE ANN. tit. 8 § 170 (2012) (permitting issuance of dividends only when a surplus exists).

98. See Clark, supra note 75, at 511 (explaining that a transfer does not violate the ideal of Truth when the transaction is "fully and truthfully described").

99. As interpreted by the Supreme Court, the Bankruptcy Code creates an unfortunate exception upon the filing of a bankruptcy petition. Moore v. Bay, 284 U.S. 4 (1931). The Code allows the trustee to avoid transfers as though he were a hypothetical creditor without knowledge of or acquiescence in the transfer, and directs him to share the proceeds of any recovery ratably according to the priority of allowed claimants' claims. 11 U.S.C. § 544(b) (2012). This rule is indifferent to the fact that two creditors may have starkly different justifications in challenging a debtor's transfer as fraudulent. It permits double recovery for creditors who advanced funds knowing of the challenged transfer and leaves in the cold those who did not. Thus I join the chorus of commentators who reject the doctrine of Moore. See Douglas J. Whaley, The Dangerous Doctrine of Moore v. Bay, 82 TEX. L. REv. 73, 74 (2003) ("The villain is the doctrine of Moore v. Bay, which ... allows the bankruptcy trustee to assume the rights of the [unsecured creditors] ... and then to improve their priority position by fitting into it all claims filed in the [debtor's] bankruptcy proceeding, thus exhausting the value of the collateral and squeezing out the junior perfected creditors."). 
Let us return to the question of how a manager ought to dispose of firm assets in the face of vertical investor conflict and ask what fraudulent transfer teaches. As we have seen, the traditional account of fiduciary duty asks the manager to maximize the return of assets to the firm's shareholders. ${ }^{100}$ When the firm is financially healthy, this means finding projects that increase the expected value of the firm's assets. But when the firm is financially distressed - when its debt-to-assets ratio approaches 1 - the manager can maximize shareholder returns through projects that entail negative expected value but also a high variance of returns. This is the lesson of Part II. Fraudulent transfer doctrine constrains the manager. Another way to put the point is to say that the shareholder-wealth maximization norm is subject to the constraint of fiduciary duty. The manager must seek to maximize shareholder returns subject to the rule that he may not accomplish this aim by reducing the net expected value of the assets to the shareholders and creditors combined. In other words, the manager may seek to profit shareholders only by undertaking positive expected-value projects. In choosing between two mutually exclusive projects, one with a high expected value that, because of the variance of its payouts, will impair creditors, and one that is safe but with a low expected value, the manager can and should choose the high-risk, high-value project.

The logic implies a reciprocal rule. Suppose now that the high-value project is also the safe one and that the low-value project would benefit shareholders only because of its risk properties. Fraudulent transfer forbids the manager from choosing the risky, low-value project. The manager must in this case choose the project favored by the creditors. The synthesis of the two rules states an ideal of asset-value maximization. The manager ought to employ the firm's assets in a way that maximizes their aggregate value to all the firm's investorsshareholders and creditors.

One could object that fraudulent transfer touches only transfers and never condemns the status quo. Fraudulent transfer, that is, never obliges a debtor firm actively to do anything with its assets. The firm need not reduce the risk its operations entail just because a higher-value project is available. Although such an action-inaction distinction is well taken on formal grounds, it cannot have much to say about the world of

100. Bo Becker \& Per Strömberg, Fiduciary Duties and Equity-Debtholder Conflicts, 25 Rev. Fin. Stud. 1931, 1931 (2012). See also Katz v. Oak Indus. Inc., 508 A.2d 873, 879 (Del. Ch. 1986) (extending directors' fiduciary duty only to shareholders). 
modern business. In the business world there is formally speaking no status quo. The most routine operations are accomplished through countless "transfers" within the meaning of any conveyance law.

The skeptical reader will notice another question of baseline, one that at first glance appears more sophisticated. Suppose that a highly leveraged firm faces three mutually exclusive possibilities. First, it may pursue its status quo portfolio of projects. Second, it can undertake a project that in expectation promises to net the firm $\$ 10$ more than the status quo but that will entail a high variance of possible returns. Third, the firm can choose a project that guarantees $\$ 15$ more than the status quo portfolio. It should by now be clear enough that the firm's manager is obliged to do something other than the status quo. But must he choose the third (highest value) project? Our discussion of fraudulent transfer concluded that a debtor is permitted to impair creditor interests if in so doing the debtor increases the expected value of its assets. ${ }^{101}$ If the appropriate baseline is the status quo, then the second project is acceptable, and, according to our traditional statement of fiduciary duty, the manager should choose it if it maximizes the shareholders' expected return. But suppose the manager in fact chooses this high-variance project. Now the low-value, high-risk project becomes the status quo. The problem dissolves into the binary choice described above. Setting aside the action-inaction distinction, the manager will be obliged to trade up, so to speak, to the highest-value project.

$$
* * *
$$

In the real world, of course, the expected values of a firm's opportunities are difficult or perhaps impossible to determine with precision. It is even doubtful to what extent an outsider can know what opportunities the firm realistically has. The law's response has been to defer in most cases to the judgments of a firm's management. When shareholders sue and assert a violation of fiduciary obligation, this discretion is known as the business judgment rule. When a creditor objects to a firm's disposition of assets on a theory of fraudulent transfer, discretion is embodied in the rule that the creditor must prove intent to delay, hinder, or defraud. By definition, deference means that often law will not discipline a manager who flouts the asset-value-maximization

101. See supra notes $96 \& 97$ and accompanying text. 
norm.

This Part has aimed to abstract from the real world - to forget for a moment the evidentiary burdens and presumptions that color real-world litigation - and to discern what the law directs a conscientious manager to do. Undoubtedly most managers care what the law says, just because it is law, about how they ought to exercise their discretion. Anyone who stops at red lights in the middle of the night will understand why. And empirical work suggests that manager behavior does in fact change when the standard of conduct to which they are held changes, even when the threat of successful challenges in litigation is held constant. ${ }^{102}$ Think of this as a function of law's expressive value.

Expressive value is only a part of the matter, though. Business managers are no saints. Accepting that managers will inevitably enjoy some latitude because of the real-world limitations of courts (and the costs of judicial intervention), ${ }^{103}$ one needs to ask whether an interventionist program is justifiable; and, if so, under what conditions.

\section{THE PROSPECT OF LEGAL INTERVENTION}

The lesson of Parts II and III can be summarized neatly. The law asks a firm's manager to resolve vertical investor conflict by pursuing projects likely to maximize the expected value of the firm's assets to shareholders and creditors combined. In some circumstances, assetvalue maximization will be the manager's natural aim. When the manager's private profit identity is equally weighted between shareholder and creditor interest, she will seek value-maximizing projects without any legal intervention. ${ }^{104}$ But with anything short of a complete theory of human behavior, one can estimate the manager's profit identity with only very limited accuracy. It is safe to presume that the manager will be inclined to a more risk-neutral strategy than either the firm's shareholders or its creditors will be, but it is not obvious

102. See Becker \& Strömberg, supra note 100, at 1932-34 (showing changes in managerial behavior in firms near insolvency following Credit Lyonnais). Credit Lyonnais told managers to consider creditor as well as shareholder interests "in the vicinity of insolvency," but it did not articulate any standard by which creditors might enforce this new obligation. Nevertheless, Becker and Strömberg have identified significant changes in firm behavior after Credit Lyonnais. In particular, they found that firms reduced risk, increased leverage, and relied less on explicit covenants. Id.

103. See Baird \& Henderson, supra note 9, at 1313 (discussing the inability of courts to easily or effectively determine the legality of a director's actions).

104. See supra Part II.B. 
except in the extreme case whether the manager will pursue a riskseeking or a risk-averse strategy. That is, it is not obvious as a matter of theory whether the manager's deviation from the legal norm is more likely to state a case of fiduciary slack or fraudulent transfer. In particular, the existence of a dissatisfied shareholder or creditor class reveals little about the degree to which the manager has departed from the risk-neutral attitude the law directs. Inasmuch as the manager's apparent risk tolerance will generally be intermediate, one should expect that both shareholders and creditors will be unhappy with it to some degree. ${ }^{105}$

A costless mechanism to enforce asset-value maximization would reduce managerial bonding costs as well as the monitoring costs of both debt and equity. It would thus decrease firms' total cost of capital. But if the most one can say of managerial incentives is that they are ambiguous, it is natural to ask how law could possibly ameliorate vertical investor conflict at acceptable cost. Litigation is expensive. Without a stable presumption about the direction in or degree to which management is likely to depart from the value-maximizing norm, litigation would seem to threaten significant error costs in addition to unavoidable administrative costs.

Moreover, a coherent evaluation of law's place in resolving vertical investor conflict depends on one's view of capital markets' relative efficiency. Investors are well aware of conflicts between hierarchically differentiated capital suppliers. Given the inherent costs of litigation, one must ask whether investors can solve conflicts more cheaply than courts. And to the extent markets have eschewed an apparent resolution to the problem, one needs to ask why. Solutions entail costs. If the costs of eradicating an evident problem exceed the costs of the problem itself, then the solution is itself a new problem. Indeed, decisions such as Credit Lyonnais and Gheewalla are probably best read as an implicit ratification of this skeptical view. In directing managerial loyalty to a "community of interests," Delaware has effectively denied that there is any particular metric by which courts can assess a manager's deviation from the ideal, value-maximizing attitude. Without a standard of evaluation, the business judgment rule takes on nearly insuperable proportions. Laissez faire seems to be Delaware's doctrine when it

105. Laura Lin pointed out this difficulty with respect to creditor challenges. Lin, supra note 8, at 1509 . But for reasons that should by now be clear, a shareholder's incentive to challenge valuemaximizing projects is equal to and reciprocal of a creditor's. 
comes to vertical investor conflict.

But is it true that law is generally incapable of encouraging selfinterested managers to live up to the value-maximization ideal? Broadly speaking, the law might seek to resolve vertical investor conflict through either ex ante or ex post regulation, or through a combination of both. Ex ante regulation seeks to align the incentives of primary actors with the social good. Here that means a strategy aimed at making investors and managers prefer asset-value maximizing projects. Ex post regulation seeks the same end, but does so by threat of punishment for deviation from the ideal norm. It is regulation by litigation. This Part tentatively argues that ex ante legal intervention holds little promise. With respect to litigation, this Part argues that Delaware's skeptical attitude is well taken in the context of closely held firms, but that deference to management is less justified when investors in a public firm allege breach of fiduciary obligation or fraudulent transfer.

\section{A. Ex Ante Regulation}

1. Harmonizing Investor Incentives

As we saw in Part II, vertical investor conflict is a function of limited liability and in particular the hierarchical nature of investors' claims on firm assets. One way in which law can resolve this conflict is through rules harmonizing investor profit identities. Reducing the divergence of interest between shareholders and creditors reduces the effect of risk on the expected profit of each. Reducing the effect of risk in turn reduces the investors' incentives to lobby management for low expected-value projects that redound to the particular class's advantage. To take an extreme possibility, imagine that shareholders and creditors were made to internalize identical profit identities, in the case of a dual-class firm each class bearing half of the other's losses. This would solve vertical investor conflict outright because it would make the investors' cash-flow rights identical.

One example of a harmonizing rule found in our law is forced conversion. In a bona fide Chapter 11 reorganization, the bankruptcy judge is empowered to convert a creditor's prepetition debt interest in the debtor firm into an equity interest in the reorganized entity. ${ }^{106}$ If need be,

106. See In re AutoStyle Plastics, Inc., 269 F.3d 726, 748 (6th Cir. 2001) (holding that a bankruptcy court can consider whether to characterize a claim of debt as equity). 
the bankruptcy judge can accomplish this through "cram down," 107 and thus negotiations during bankruptcy reflect the possibility of at least partial conversion. Even before bankruptcy, therefore, the threat of conversion affects a rational creditor's profit identity. If the creditor thinks there is a 30 percent chance of conversion into equity tomorrowor, what comes to the same thing, if the creditor believes that 30 percent of his interest will be converted - then his own profit identity will reflect shareholders' interests proportionally. This creditor will be marginally less likely, pre-bankruptcy, to agitate for value-destroying safe projects. Commentators who advocate a loss "sharing" regime, rather than a presumption of liquidation and distribution according to state law priorities, have in fact sought (perhaps unwittingly) a rule ameliorating vertical investor conflict. ${ }^{108}$

But although robust conversion rules have the potential to eliminate vertical investor conflict, one should be wary of their place in debtorcreditor law. Conversion rules reduce conflict because they flatten a firm's capital structure. Creditors in a world of robust conversion are less likely to seek safe, low-value projects because they know that, at the end of the day, only a fraction of their priority will be respected. Shareholders in such a world know that they bear the residual interest only to a degree. In terms of cash-flow rights, the investors become homogeneous; at the limit, they find themselves in a world of equity-only or debt-only firms.

Yet notwithstanding vertical investor conflict and Modigliani and Miller's famous riddle, ${ }^{109}$ capital markets continue to generate hierarchically differentiated capital structures. Financial economists and legal scholars have identified a number of plausible explanations. For one thing, hierarchical differentiation may optimize the monitoring of a firm's management. ${ }^{110}$ It may, in other words, reduce managerial selfdealing by more than the expected cost of vertical investor conflict. One has to be skeptical of legal rules that undermine the choices voluntary

107. 11 U.S.C. $§ 1129(b)(1)(2012)$.

108. E.g., Elizabeth Warren, Bankruptcy Policy, 54 U. CHI. L. REV. 775 (1987). Interestingly, bankruptcy law is asymmetric in its appetite for conversion. A creditor's interest may be converted, but not a shareholder's. In other words, the bankruptcy judge cannot call on shareholders for additional capital - a forced "loan" that would to some degree force shareholders to internalize lenders' losses.

109. Franco Modigliani \& Merton H. Miller, The Cost of Capital, Corporation Finance and the Theory of Investment, 48 AM. ECON. REV. 261, 268-69 (1958) (establishing the theory that a firm's form of capital financing is irrelevant to its market value).

110. See, Levmore, supra note 36 , at 50. 
investors make.

To say that law has no place here is not to diminish the insight that conversion - indeed, even the possibility of conversion - reduces vertical investor conflict. Financial economists have suggested that firms use convertible instruments for precisely this reason. ${ }^{11}$ This is a voluntary rather than mandatory conversion rule, but the incentive dynamic works similarly. And indeed, empirical research suggests that financially troubled firms (in which vertical investor conflict is most acute) are more likely than others to issue convertible bonds. ${ }^{112}$ The point is rather that law with its one-size-fits-all tendency is unlikely to do better than private markets in creating optimal conversion rights.

A different harmonizing rule would unify investor interests by forcing auction to a single buyer whenever a firm's debt-to-assets ratio exceeds an identifiable threshold. ${ }^{113}$ Recall that the sole owner of assets maximizes his profit by maximizing asset value. ${ }^{114}$ In large measure, modern bankruptcy practice is devoted to this aim. Whether through a section 363 sale or by the terms of a plan of reorganization, most Chapter 11 proceedings are resolved by putting the debtor's assets in the hands of a single, willing buyer. ${ }^{115}$ Even when a debtor firm does not sell all of its assets, it often sells a portion of them to generate cash, pay down debt claims, and thereby restore the firm's debt-to-assets ratio to an

111. Jensen and Meckling were the first to see this. According to their pathbreaking article, "[T] he addition of a conversion privilege to fixed claims such as debt or preferred stock would also tend to reduce the incentive effects of the existence of such fixed claims and therefore lower the agency costs associated with them." Jensen \& Meckling, supra note 20, at 354. See also Smith \& Warner, supra note 28, at 140-42 (discussing Jensen and Meckling's work and noting that not all debt contracts include a conversion privilege due to the accompanying expenses); but see M. P. Narayanan, On the Resolution of Agency Problems by Complex Financial Instruments: A Comment, 42 J. FIN. 1083, 1087-88 (1987) (taking issue with the argument that conversion necessarily resolves vertical investor conflict).

112. Joshua D. Rauh \& Amir Sufi, Capital Structure and Debt Structure, 23 REv. FIN. STUD. 4242, 4245 (2010); Michael J. Brennan \& Eduardo S. Schwartz, The Case for Convertibles, 1 J. APPLIED CORP. FIN. 55, 64 (1988).

113. In many respects such a rule would serve the same purpose as minimum-capital requirements pervasive in the European Union. In the United States, however, minimum-capital rules are unrealistic outside heavily regulated industries such as banking and insurance. For a persuasive argument against the utility of minimum-capital rules, even if they were politically feasible, see Luca Enriques \& Jonathan R. Macey, Creditors Versus Capital Formation: The Case Against the European Legal Capital Rules, 86 CORNELl L. REV. 1165 (2001).

114. See supra Part II.A.

115. See Douglas G. Baird \& Robert K. Rasmussen, Chapter 11 at Twilight, 56 STAN. L. Rev. 673,679 (2003) (finding that in $200284 \%$ of Chapter 11 proceedings were asset sales or preexisting deals). 
acceptable level. ${ }^{116}$ One might describe Chapter 11 as standing for a de facto if not de jure mandatory-auction principle.

For at least two reasons, though, one should hesitate at the prospect of a mandatory-auction rule. First, asset sales collapse the option value inherent in the junior interests. ${ }^{17}$ One can think of an asset sale as a zero-risk investment, and thus as the kind of project for which creditors will agitate even (in some cases) where the assets' value to the firm is greater than what the highest outside bidder will pay. In a world of asymmetric information, this may often be the case. ${ }^{118}$ The concern is that investors in a mandatory-auction regime will act strategically on the margins near whatever debt-to-assets threshold the law might select. ${ }^{119}$ Creditors, in particular, may perversely seek negative returns in the short run in order to activate the mandatory auction. For their part, shareholders might seek short-run measures that decrease the firm's immediate debt-to-assets ratio at the expense of long-run growth opportunities. $^{120}$

To some degree capital markets appear willing to tolerate the perversion of incentives associated with a forced sale. In many debt contracts, firms covenant not to allow their debt-equity ratio to grow beyond a stated threshold. The creditor of a breaching firm then has the option to declare a default and force the firm into bankruptcy where an asset sale is likely. ${ }^{121}$ Again, though, one must ask why the law should intervene if investors are capable of crafting mandatory auction rules where they please. ${ }^{122}$ Here, the law's inflexibility is of particular concern. The degree to which vertical investor conflict will pose a real and not merely theoretical threat to the efficient use of assets will depend upon factors such as the firm's size and the industry in which the firm operates. ${ }^{123}$ Investors can haggle over details. A statute is, by contrast, a

116. Id. at 675-76, 691-93 (discussing the prevalence and role of asset sales in Chapter 11 proceedings).

117. Anthony J. Casey, The Creditors' Bargain and Option-Preservation Priority in Chapter 11, 78 U. CHI. L. REv. 759, 764-65 (2011).

118. Id. at 788 .

119. See id. at 784-89 (discussing the conflicting interests of junior and senior creditors when the mandatory absolute priority rule is applied).

120. Casey argues that bankruptcy can preserve option value in asset sales by relaxing the absolute-priority rule. Id. at 789-96. Another approach, which I hope to specify in subsequent research, would require the sale of the investors' interests rather than the firm's assets.

121. Baird \& Rasmussen, supra note 115, at 679.

122. See id. at 696 .

123. See id. 
blunt tool indeed.

\section{Regulating Managerial Incentives}

A second approach to ex ante regulation focuses on managerial incentives. As we have seen, a manager's profit identity is a weighted average of the profit identities of the firm's investors. In a two-tranche firm such as Part II modeled, vertical investor conflict threatens to impose social costs only when the manager's profit identity is not equally weighted between the interests of shareholders and creditors. Thus, a legal rule forcing managers to weigh investor interests proportionally to the size of their claims would alleviate the effects of investor conflict without seeking to harmonize the investors' own incentives.

The most obvious route is a legal rule mandating that compensation be tied to changes in the value of a firm's assets (including assets taken out of corporate solution as dividends or to pay down debt). ${ }^{124}$ The idea entails obvious practical difficulties. Firms are financed from many directions. A firm may owe obligations on a bank loan (including revolving facilities under which the outstanding amount of debt fluctuates), multiple bond issues with varying maturities, trade debt with varying terms, employee contracts, and involuntary, sometimes contingent and uncertain, tax and tort claims, all in addition to, of course, equity. Changes in financing would require firms continually to update compensation contracts. The practical inconvenience may explain, in part, why we do not observe firms offering such detailed, tailored compensation packages. But in any event, there is little reason to think law can achieve more in this regard than private markets can.

In particular, law seems ill-suited to the heterogeneity of managerial preferences. This Article has assumed throughout that investors and managers reveal symmetric tolerance for risk. It has been a convenient assumption for purposes of exposition, but of course people in the real

124. See generally Baird \& Henderson, supra note 9 (discussing contractual pay-setting for managers of firms in Chapter 11); see also Jensen \& Meckling, supra note 20, at 352 ("If [the manager] binds himself contractually to hold a fraction of the total debt equal to his fractional ownership of the total equity he would have no incentive whatsoever to reallocate wealth from the debtholders to the stockholders."). Delayed compensation probably does this, as do pension plans. The idea is to make the manager a kind of "sole owner." If she has to internalize the costs shareholders' preferences impose on debtholders, and vice versa, in proportion to the size of investment in each tranche, the manager ought to internalize the social cost of preferring any one group of investors. 
world differ on this score. Some scholars have theorized that managers are systematically risk-averse, relative to the suppliers of capital, when it comes to the firm's activities. ${ }^{125}$ Unlike most passive investors, senior executives are expected and at times required to invest a substantial part of their personal wealth in the firm. Diversification is more difficult, perhaps impossible, and consequently management may be inclined to reduce the variance of the firm's prospects. Others believe that the personality likely to rise to a position of senior management, at least in a big firm, tends toward the risk-seeking. ${ }^{126}$ There is no need here to take a position on which thesis is empirically correct, if either. Whatever the average direction of managerial risk preferences, there is doubtless variation among particular managers. If investors, in a given firm, believe that their CEO is a risk seeker, or is risk averse, they may want to tailor her compensation package to fit the facts. Law's cumbersome uniformity is not well adapted to deploy hunches or respond to subtle behavioral signals.

$$
* * *
$$

This discussion should suggest skepticism about the law's ability, relative to that of capital markets, to resolve vertical investor conflict through ex ante regulation. The reason is clear enough: wherever the law can furnish a workable ex ante rule, capital markets can do the same. And unlike the law, which because of administrative and decision costs tends to issue one-size-fits-all doctrines, investors in capital markets can tailor ex ante rules to fit the occasion. The domain of investor conflict does not seem to be one in which an impartial regulator is better equipped than self-interested investors who are fully aware of the problem they face.

\section{B. Ex Post Regulation}

Ex post regulation seeks to discipline the manager, to force her to choose asset-value maximizing projects, by permitting investors to challenge the legality of her preferred projects. It assigns decisionmaking authority to managers in the first instance. If, however, an investor can prove that the manager would have selected a different

125. See supra note 38 .

126. See supra note 38 . 
portfolio of projects had she acted with the risk-neutral attitude associated with socially optimal use of assets, a court may substitute its own judgment for that of the manager.

As Part III showed, our law currently foresees a measure of this kind of ex post regulation. Disaffected shareholders can seek to set aside managerial decisions in a suit alleging breach of fiduciary duty. A successful claim entitles the shareholder plaintiff to injunctive relief, directing management to undertake the proper course of action, or else compensatory damages. ${ }^{127}$ Disappointed creditors have an analogous cause of action. They can challenge managerial decisions in a fraudulent transfer suit against the debtor firm. Here, too, courts are authorized to enjoin pending transactions or to set them aside after the fact. ${ }^{128}$

We might think investor suits hold little promise of effectively regulating managerial incentives. The manager's profit identity is difficult to estimate in any given case, because of uncertainty about the relative weight she will give to shareholder and creditor interests. Investors and managers may differ in their estimation of the risks and rewards of various possible projects, a version of the "balance-sheet" conflict referred to in Part II. Because it is difficult to estimate a manager's profit identity in any given case, courts will often be unable to calibrate a prima facie view of the skepticism with which they evaluate the manager's actions. In other words, courts may find it hard to tell whether a manager has adopted a course of action out of favoritism toward a class of the firm's investors or, rather, because of genuine belief that it is the asset-value maximizing strategy.

Indeed, courts are well aware of this problem. The deference they grant to managerial decisions reflects the difficulty. ${ }^{129}$ Yet it is worth asking whether deference is in all cases equally merited. For firms whose securities are widely traded, market prices may provide valuable insight. To see this, consider again the Acme hypothetical from Part II. Assume that Acme's equity and debt are traded in liquid markets. Additionally, assume that the manager and investors know, or at least agree on, the payout possibilities of Acme's three possible projects, but that a court is incapable of discovering the information directly. At time

127. E.g., Omnicare, Inc. v. NCS Healthcare, Inc., 818 A.2d 914, 939 (Del. 2003).

128. UNIF. FraudulENT TRANSFER ACT $\S 7$ (a)(1), 7A U.L.A. 155 (2006).

129. See, e.g., In re Citigroup S'holder Deriv. Litig., 964 A.2d 106, 126 (Del. Ch. 2009) ("It is almost impossible for a court, in hindsight, to determine whether the directors of a company properly evaluated risk and thus made the 'right' business decision."). 
0 , Acme's equity is trading for $E_{0}$ and its debt for $P_{0}$. Suppose first that the manager announces that Acme will pursue Project $A$. Shareholders are elated. The market reacts to the news by trading up the value of equity to $E_{0}+\$ 17.50$. The creditor, on the other hand, is disappointed. The market now prices his debt at $P_{0}-\$ 37.50$. If the creditor files suit on a fraudulent transfer theory, what result? Consulting the price fluctuations, the court will see that Acme has reduced the creditor's expected recovery without increasing the expected value of its assets to the investors as a group. Before the announcement, the market valued Acme's assets at $E_{0}+P_{0}$. Now it values them at $E_{0}+P_{0}-20$. This is a fraudulent transfer.

Note that shareholders would hold a reciprocal and viable complaint if management selected Project $B$. The claim would be described as a breach of the duty of loyalty. Project $C$ presents the interesting case. If Acme pursues Project $C$, the market price of shareholders' equity increases to $E_{0}+\$ 7.50$. The price of the creditor's debt declines to $P_{0}-$ $\$ 2.50$. Now what result if the creditor brings a fraudulent transfer action? The answer is no liability. As in the case of Project A, Acme has reduced the creditor's expected recovery. But it has done so by choosing a project that increases the total value of its assets. The market now values Acme's assets at $E_{0}+P_{0}-5$. The manager has made a proper decision.

This hypothetical suggests a more general conclusion. If liquid markets efficiently price each class of debt and equity a firm issues, then courts can get a rough sense of the merit of an investor's suit by comparing prices before and after the announcement of a strategic initiative. ${ }^{130}$ If the price of the plaintiff's investment has increased, there is no liability. If the price of the plaintiff's investment has decreased but the implied price of the assets as a whole has increased, there is no liability. Only when the price of the plaintiff's investment and the implied value of the firm's assets have declined in value, but yet the value of another class of investment has increased, is there cause to think management favoritism is to blame. ${ }^{131}$ This is not to say liability would follow as a matter of course in such a case. Maybe the manager has private information about the risks and rewards of the project she has

130. The court would of course have to extrapolate from market changes to estimate the price fluctuation of untraded investments such as trade debt and tort claims.

131. C.f. Baird \& Henderson, supra note 9, at 1326 (suggesting the notion behind Credit Lyonnais is that a "fiduciary duty owed to shareholders should not prevent the directors from taking actions that were in the creditors' interest and in the interest of the firm as a whole"). 
selected, information necessarily not included in market prices. But here at least the facts suggest that a deeper inquiry into the manager's motives may be in order. In a sense, market signals promise to reduce litigation costs by filtering meritless from potentially meritorious claims.

Market signals may be valuable even where a court lacks access to the pricing of every class of investment. The only crucial data is the firm's equity and options on the same trade in a liquid market. Option theory tells us that the value of an option depends on, among other things, the underlying asset's volatility. ${ }^{132}$ Widely used pricing models such as Black-Scholes reveal the implied volatility of equity (the square of equity's variance). ${ }^{133}$ Comparing the implied volatility of a firm's equity before and after the announcement of a strategic initiative thus reveals the market's evaluation of the change in its volatility attributable to the announced plan. As Part II showed, shareholders' and creditors' profit identities depend on both the expected value of the firm's projects and their variance. A change in the price of equity reflects a change in (a) the expected value of the firm's assets, (b) the expected variance inherent in the firm's business, or (c) both. Using an option pricing model to estimate variance, one can mechanically calculate whether, to what degree, and in what direction these factors contributed to changes in the value of an investment. Deriving variance from changes in option prices is in some ways more complicated than direct observation. But it would allow mathematically inclined courts to screen meritless cases where not all of a firm's debt and equity trade in liquid markets.

The skeptical reader may again object that this discussion assumes a stable baseline against which managerial decisions are to be judged. Suppose that a firm faces three possible strategic initiatives: the status $q u o$ and two alternatives, one of which entails high risk and one low risk. Although both of the alternative projects will in expectation increase the value of the firm's assets relative to the status quo, one is more valuable than the other. How, the skeptic might ask, will investor suits direct the manager toward the highest-value project? Capital markets will in either case reflect an increase in the value of the firm's assets, and thus, the

132. See Arthur E. Wilmarth, Jr., The Transformation of the U.S. Financial Services Industry, 1975-2000: Competition, Consolidation, and Increased Risks, 2002 U. ILL. L. REV. 215, 343 (2002) (stating that an underlying asset's "anticipated volatility" is one of several factors influencing the value of an option).

133. See id. ("The Black-Scholes model simplifies the problem of estimating volatility ...."). See generally Fischer Black \& Myron Scholes, The Pricing of Options and Corporate Liabilities, 81 J. POL. ECON. 637 (1973). 
objection goes, courts would find liability in neither case. The manager has free reign.

The significance of the skeptic's objection turns on one's view of the efficiency of capital markets. If market prices at time 0 do not accurately reflect the firm's possible projects in addition to its status quo operations, then prices will only imperfectly signal managerial malfeasance. Highly efficient markets price information quickly and accurately. Anyone who watches the ticker tape after a firm announces quarterly results knows that markets do indeed price public information quickly. It is less obvious that they price private information accurately. Suppose a firm's CEO is considering whether to undertake a project, call it $Y$. At the same time, she learns of a prospective business deal, $Z$, the firm could reach with another company. $Z$ would make the firm a handsome profit, in expectation, but it would also entail high risk. Because her interests are roughly aligned with the interests of senior creditors, the CEO keeps quiet about $Z$ and goes forward with the less profitable $Y$. Or she may misrepresent her real views about $Z$ 's profitability. To the extent markets are bad at determining what possibilities are reasonably available, they will be relatively unhelpful to a court's assessment of malfeasance in an investor suit.

These are credible concerns. It should be stressed that market data will not costlessly resolve investor suits. They will not resolve vertical investor conflict perfectly. Yet in the case of a firm with widely traded securities, market prices can tell us something about whether a manager has consciously changed the firm's risk profile, and whether the change is likely to have increased or decreased the expected value of the firm's assets.

The close firm presents a less sanguine view of the promise of judicial intervention. By definition, investments in a close firm are not widely traded. Courts do not have access to the opinions disinterested market watchers hold on the nature of managerial decisions. The say-so of interested investors is the best evidence a judge will realistically hear. We have seen that a manager's risk appetite at a given time is likely to be greater than a creditor's but less than a shareholder's. The manager's choice of projects will tend to entail too much risk for the creditor but too little for the shareholder. Both classes of investor could gripe. Indeed, in a distressed firm, socially optimal investments satisfy neither shareholder nor creditor. The existence of dispute then says nothing about whether and to what extent a manager has deviated from the decisional ideal our law supplies. Short of damning documentary evidence, courts will find it difficult to figure what exactly caused a manager's decision. In a close 
firm, ex post regulation through investor suits seems an unhelpful way to resolve investor conflict.

On the other hand, the deleterious social effects of conflict are perhaps less significant in a close firm. The investors in a close firm are fewer in number than investors in a public corporation. They are also likely on average to know more about the firm's business. The freeriding problem is smaller and hence the returns to active monitoring are greater. In this sense the close firm approaches a rough description of Coase's utopia. Holdout and freerider problems are small, as are the costs of negotiation. Information asymmetries are few and far between. The investors can cheaply negotiate with one another or bribe management. Their ex post dickering predictably ends with the firm putting its assets to their best use. Thus, as in so many places, Coase comes to the rescue when the situation appeared most dire.

\section{CONCLUSION}

Vertical conflict is not a sign of perverse or idiosyncratic investor behavior. On the contrary, it is a product of rational self-interest in the presence of limited liability. Wherever investor claims to a firm's assets are hierarchically organized, vertical investor conflict should be expected and socially suboptimal use of assets should be feared. The question is what, if anything, law has to say about the way in which managers resolve the conflict.

This Article has aimed to show that our law has much to say, at least when it comes to articulating ideals toward which managers should strive. The combined lesson of fraudulent transfer doctrine and the duty of loyalty, as traditionally framed, is that a manager ought to seek strategies that maximize the expected value of her firm's assets. This is a descriptive take on the law, but it has the happy consequence of mirroring the rule that most economists believe investors would agree to in a hypothetical, ex ante negotiation. In this sense, asset-value maximization can be understood as a default norm of corporate and debtor-creditor law.

Whether law can do much good enforcing the norm is a harder question. I suspect that one's conclusion on this score will depend on one's priors about the efficiency with which and manner in which capital markets speak to vertical investor conflict. Tailored compensation packages, coupled with the threat (or promise) of takeover by a single owner, may go far in remedying the problem. But market regulation appears imperfect. To those who believe that prices do a good job of 
reflecting the underlying state of affairs in a firm, suits charging violation of fiduciary obligation or fraudulent transfer may seem a valuable complement. 